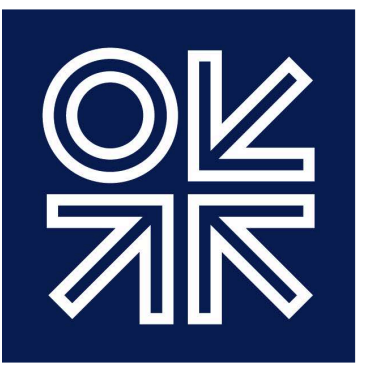

THE OXFORD

INSTITUTE

FOR ENERGY

STUDIES

\title{
The April 2010 Russo-Ukrainian gas agreement and its implications for Europe
}

Simon Pirani, Jonathan Stern and Katja Yafimava

NG 42

June 2010 
The contents of this paper are the authors' sole responsibility. They do not necessarily represent the views of the Oxford Institute for Energy Studies or any of its members.

Copyright (C) 2010

Oxford Institute for Energy Studies

(Registered Charity, No. 286084)

This publication may be reproduced in part for educational or non-profit purposes without special permission from the copyright holder, provided acknowledgment of the source is made. No use of this publication may be made for resale or for any other commercial purpose whatsoever without prior permission in writing from the Oxford Institute for Energy Studies.

ISBN

978-1-907555-12-1 


\section{CONTENTS}

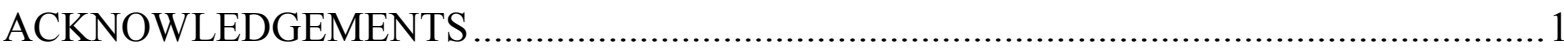

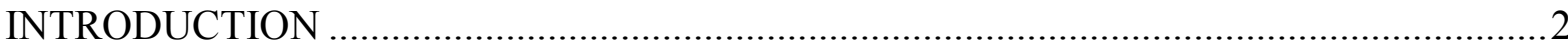

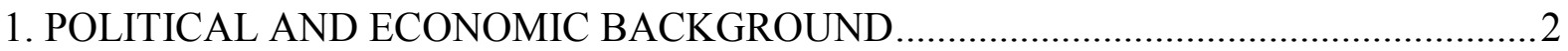

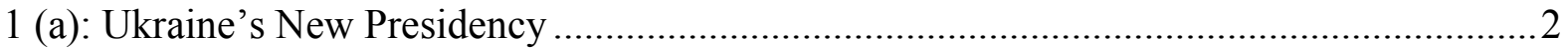

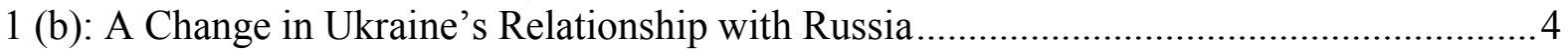

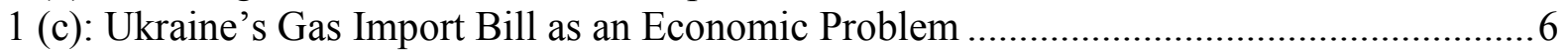

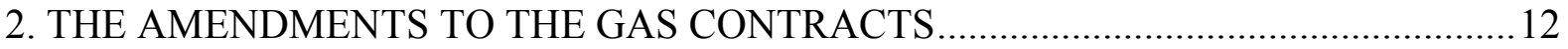

2(a): The Results of the Renegotiation, and Why They May Not Last .................................. 12

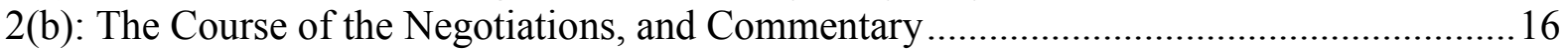

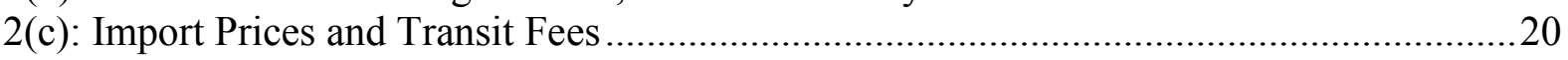

2(d): The Agreement from a Russian Standpoint: a Political Discount.................................22

2(e): The Russian-Ukrainian Deal in a European Gas Market Context.................................24

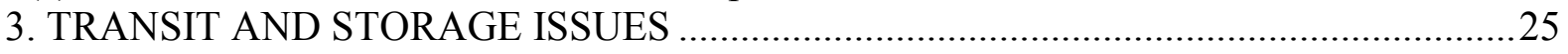

3(a): The Transit Diversification Strategy of Gazprom and its Big Customers ......................25

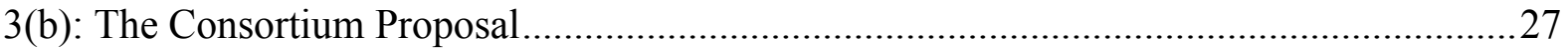

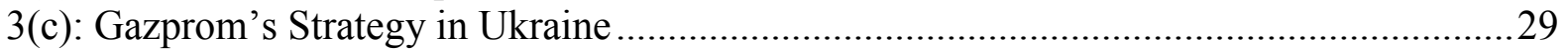

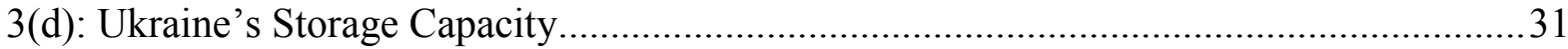

4. UKRAINE AS A GAS IMPORTER, AND ITS DOMESTIC MARKET ….....................32

4(a): Consumption and the Causes of Naftogaz's Financial Problems ....................................... 32

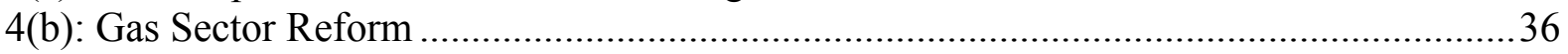

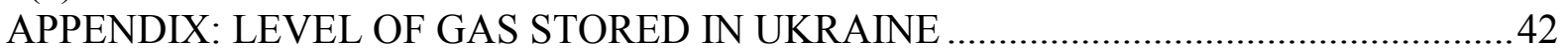

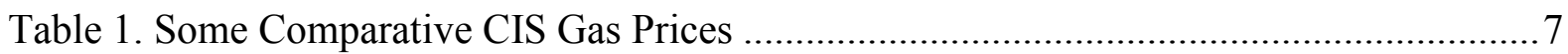

Table 2. Outline of Ukraine's gas and transit trade with Russia .........................................9

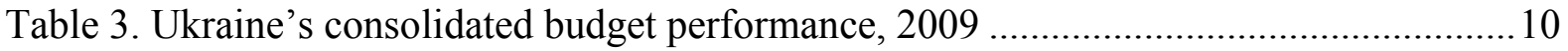

Table 4. European, Ukrainian and Belarussian Gas Prices Compared ...................................20

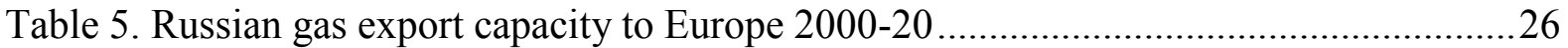

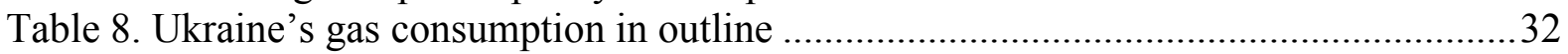

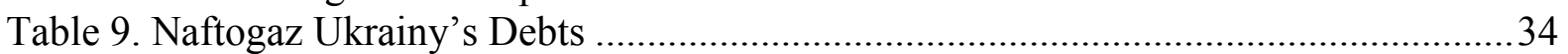

Table 1A. Estimated levels of active gas stored in Ukraine ................................................4

Chart 1A. OIES estimates of the level of active gas stored in Ukraine, bcm ........................ 45

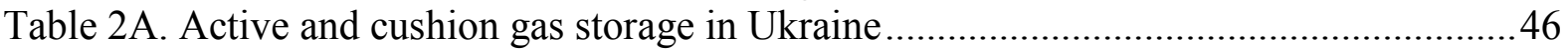




\section{ACKNOWLEDGEMENTS}

The authors thank for their advice and help Christine Cooper, John Elkins, Mikhail Gonchar, Tim Gould, Anouk Honore, Howard Rogers and Sergey Trigolov. All the views expressed and mistakes made are our own. 


\section{INTRODUCTION}

An agreement signed on 21 April 2010 by Russian president Dmitry Medvedev and his newly-elected Ukrainian counterpart Viktor Yanukovich provided for a 30\% discount on Russian gas imported to Ukraine, in return for a 25-year extension of the lease to Russia of the Black Sea naval base at Sevastopol. The agreement came along with declarations from both sides that political and diplomatic relationships would improve after the departure of Yanukovich's predecessor Viktor Yushchenko, whose pronounced pro-western foreign policy, centred on NATO accession, was distrusted in Moscow. There followed a flurry of other proposals for deeper Russo-Ukrainian cooperation - in the electricity generation, atomic, aerospace and telecoms sectors, among others. This article considers the significance of the new agreement with Russia, (a) for Ukraine as a gas transit country, and for the European states that rely on Russian imports transported via Ukraine, and (b) for the Ukrainian gas market.

\section{POLITICAL AND ECONOMIC BACKGROUND}

\section{1 (a): Ukraine's New Presidency}

The year 2010 began in Ukraine with a fiercely contested presidential election campaign fought by the then prime minister, Yulia Timoshenko, and the leader of the opposition who lost the 2004 presidential elections, Viktor Yanukovich. Although the results were close, Yanukovich was declared the winner after the second round of voting on 7 February. He was able, with a rapidity that surprised many observers, to form a government headed by his close collaborator Nikolai Azarov, and to secure a coalition with a working majority in parliament. The way the coalition was formed was contested in Ukraine's Constitutional Court, but was ultimately found to be constitutional. ${ }^{1}$ The government is heavily dominated by the Party of Regions, and influenced in turn by the business groups on which the party relies for support. The principal appointment from outside the party was of Serhiy Tihipko, who came third in the presidential election, as deputy prime minister with responsibility for economic policy,

\footnotetext{
${ }^{1}$ Roman Olearchyk, 'Ukraine court upholds Yanukovich coalition', Financial Times, 9 April 2010.
} 
including Ukraine's negotiations with the IMF. Governmental responsibility for energy has been put in the hands of Andrei Klyuev, first deputy prime minister with responsibility for energy, himself a powerful industrialist with interests in the power, banking and other sectors; and Yuri Boiko, who has been reappointed minister of fuel and energy, a job he held in 2006-07, who has a close working relationship with Dmitry Firtash, co-owner of Rosukrenergo.

All recent changes of government have led to a complete overhaul of the management of Naftogaz Ukrainy, the Ukrainian national oil and gas company, and this one was no exception. Many key positions for directing the company's gas business have been taken by managers who previously worked with Boiko and/or Firtash, including: Evgeny Bakulin, CEO of Naftogaz Ukrainy, a job he held during Boiko's previous tenure as minister; Vladimir Trikolich, deputy CEO, who had two previous spells at Naftogaz, working particularly on domestic distribution; and other deputies Eduard Shvidky, Vladimir Chuprun, Yuri Kolbushkin and Yevgeny Korneichuk. Former Firtash employees have been appointed to head Naftogaz Ukrainy's two most profitable subsidiaries: Yuri Borisov at Ukrgazdobuvannya, the E\&P division, and Sergei Vinokurov at Ukrtransgaz, the transit company. Borisov is a former director of Group DF, Firtash's holding company, and both formerly worked at OST Chem Holding, a Firtash chemical company. ${ }^{2}$

The new government's determination to improve relations with Russia is unambiguous, although the fact that it will also seek to maintain and build upon Ukraine's significant economic relationship with Europe should not be ignored. The implications of this for the gas sector are discussed in the next section. The government's likely attitude to economic reforms in general, and gas sector reforms in particular, is harder to discern. In two spells as prime minister (2002-04 and 2006-07), Yanukovich pursued a pragmatic economic policy. He supported diversification of trade towards Europe and implemented reforms that helped pave the way for Ukraine's accession to the WTO in 2008, while also remaining strongly influenced by the business groups in the Party of Regions. But now the economic policy problems faced by Ukraine are quite different. The economy is emerging from a deep recession and the government has become heavily reliant on IMF funding. The Fund is demanding budget discipline, and sees energy sector reform as central to that. It is not clear

\footnotetext{
${ }^{2}$ Ganna Liuta, “Den'gi liubiat tishinu ... kabinetov”, Zerkalo Nedeli, 10 April 2010.
} 
how the government will react. On one hand, energy sector reform has been included in the government's programmatic documents and prime minister Azarov and other ministers have indicated their intention to press ahead with energy sector reform, including the gas and heat tariff increases strongly urged by the IMF. On the other, the gas reform law has not progressed in parliament, and Azarov has stated that tariffs will remain frozen this year, ${ }^{3}$ indicating a tendency simply to postpone this difficult problem (see below, section 4(b): Gas Sector Reform.)

\section{1 (b): A Change in Ukraine's Relationship with Russia}

Under former Ukrainian president Viktor Yushchenko (2005-2010), Russo-Ukrainian political relations reached their lowest ebb in post-Soviet times. This culminated in the publication in August 2009 of an open letter by Russian president Medvedev directly accusing Yushchenko of conducting an anti-Russian foreign policy. ${ }^{4}$ Russia then failed to appoint a new ambassador to Ukraine for nearly six months. Political relations between Ukraine and Russia have now improved, not so much because of Yanukovich's arrival as because of Yushchenko's departure. All the signs are that Yanukovich and his colleagues will pursue a pragmatic foreign economic policy that will seek to benefit both from this improved relationship with Russia and from continuing development of Ukraine's relationship with Europe. Changes to the Russo-Ukrainian relationship in the gas sphere should be set in this context.

In the immediate aftermath of Yanukovich's election, both sides proceeded cautiously. It was two months before any substantial progress was made. Then on 21 April presidents Yanukovich and Medvedev met in Kharkov and signed the agreement granting discounted gas in exchange for the extension of the Black Sea naval base lease. At the same time discussions began - and continue at the time of writing, in June - on a broader programme of economic cooperation. In the energy sphere, this could include (i) long-term cooperation in the nuclear industry, including up to \$5-6 billion in Russian finance for the completion of the Khmelnitskaya atomic power station; (ii) the formation of joint ventures to develop Ukraine's uranium resources, starting at the Novokonstantinovskoe deposit; (iii) joint projects in the

\footnotetext{
3 “Tarify na gaz v 2010 godu ne povysiatsia - Azarov", UNIAN press agency, 25 April 2010.

${ }^{4}$ Dmitry Medvedev, "Poslanie presidentu Ukrainy Viktoru Iushchenko", 11 August 2009, $<\mathrm{http} / / / \mathrm{kremlin} . \mathrm{ru} / \mathrm{news} / 5158>$.
} 
power sector, including construction of new generation capacity and joint export of electricity - items included in a draft intergovernmental agreement circulated for discussion in April. ${ }^{5}$ An early result of this initiative was a long-term nuclear fuel supply contract signed in June between Energoatom, the Ukrainian nuclear power generation company, and TVEL, the fuels division of the Russian state nuclear industry corporation Rosatom. ${ }^{6}$ Other questions under discussion include the formation of joint ventures in the aerospace sector and to manage the Kremenchug oil refinery, which has been the subject of a lengthy corporate conflict between Tatneft of Russia and the Privat group of Ukraine.

It should be noted, though, that no firm agreements have yet been signed on most of these issues. When presidents Medvedev and Yanukovich met again in Kyiv on 17 May, the agreements they signed were in the political sphere - on Ukrainian support for Medvedev's proposed European security treaty, and on border demarcation - while on economic issues, discussion continued in general terms. This suggests that, while public attention is on the closer political relationship and the contrast with the situation under Yushchenko, both sides continue to bargain pragmatically and self-interestedly. A similar conclusion could be drawn from the reaction to the suggestion of a merger between Gazprom and Naftogaz Ukrainy, apparently made verbally by prime minister Putin at a press conference on 30 April. Yanukovich responded by stating that such a merger would only be acceptable to Ukraine as a 50-50 deal: a statement reportedly made "in joking fashion" - which it certainly should have been, since Naftogaz's value is estimated at $10 \%$ or less of Gazprom's. The real discussion on cooperation in the gas sector then returned to themes that had been live in the early 2000s, but had been effectively shelved during Yushchenko's presidency: a possible consortium to manage the pipeline system, "with a subsequent second stage of possible additional integration", according to Russian deputy prime minister Igor Sechin; corresponding Russian commitments to minimum transit volumes; further adjustments of price; and possible revival of direct Ukrainian purchases from central Asia. ${ }^{7}$ During May, negotiations continued between Gazprom and Naftogaz about the possible formation of a 50-

\footnotetext{
${ }^{5}$ A leaked copy was published in the Ukrainian press. See "Za flots'kim paktom - energetichna okupatsiia?" Zerkalo Nedeli, 24 April 2010.

6 “Ukraina perestala raspyliat'sia na atomy", Kommersant-Ukraina, 2 June 2010.

${ }^{7}$ Roman Olearchyk, "Medvedev rules out gas deal with Ukraine", Financial Times, 17 May 2010; Polina Khimshiashvili, "Bez trenii”, Vedomosti, 18 May 2010; Elena Mazneva, “Zaprosy Kieva”, Vedomosti, 19 May 2010. The only economic agreement reportedly signed was not at political level but a cooperation agreement between VTB bank of Russia and Ukreksimbank of Ukraine.
} 
50 joint venture that would enable greater Gazprom involvement in the Ukrainian gas sector. In late May, after a meeting between Gazprom CEO Aleksei Miller and Ukrainian energy minister Yuri Boiko, it was announced that the formation of such a joint venture would be the first step towards the two companies' closer collaboration. The forms this might take are further discussed in section 3(c): Gazprom's Strategy in Ukraine, below. ${ }^{8}$

\section{1 (c): Ukraine's Gas Import Bill as an Economic Problem}

Before moving to a discussion of the new gas deal and its implications, it may be useful to put Ukraine's difficulties in paying its gas import bill into a broader economic context.

As the authors have argued elsewhere, from about 2004 Gazprom began a concerted drive to increase CIS import prices (mainly Ukraine, Belarus and Moldova) to "European netback" levels, i.e. prices commensurate with those paid by EU importers of Russian gas, minus the additional transport cost. This was allied to a drive to increase prices in the Russian domestic market similarly. The background was the steady increase in oil prices, and therefore European gas prices, from 2003 to 2008, which made the transition even more difficult for the importers. These price increases were the most important cause of a series of "gas wars" between Russia on one hand and Ukraine (most seriously in 2006 and 2009) and Belarus (most seriously in 2004 and 2007) on the other. ${ }^{9}$ While the Russian government approved of Gazprom's "European netback" policy, in practice it often held back from swift implementation, in the course of its political dealings with the importers. Thus Belarus benefited from a discount greater than Ukraine's, in return for a closer political understanding with Russia and a deal that gave Gazprom a 50\% share in its gas pipeline company Beltransgaz.

Table 1 portrays the constant upward trend of prices, and also the substantial differential between prices in Russia and the CIS on one hand and European import prices on the other, which Gazprom constantly tried to close. Note that the prices include transport costs, but

\footnotetext{
8 “Gazprom i Naftogaz nachnut sblizhenie s sovmestnogo predpriiatiia", Vedomosti, 28 May 2010; Gazprom press release, 28 May 2010.

${ }^{9}$ Earlier publications in which we have discussed these issues include Simon Pirani (ed.), Russian and CIS Gas Markets and Their Impact on Europe (Oxford, OUP, 2009); Simon Pirani, The Impact of the Economic Crisis on CIS Gas Markets (OIES, December 2009); Simon Pirani, Jonathan Stern and Katja Yafimava, The Russo-
} 
even once these are taken into account, there is still a substantial differential between European prices on one hand, and Russian and Belarussian prices on the other.

Table 1. Some Comparative CIS Gas Prices

\begin{tabular}{|l|r|r|r|r|r|r|}
\hline \$/mcm & $\mathbf{2 0 0 5}$ & $\mathbf{2 0 0 6}$ & $\mathbf{2 0 0 7}$ & $\mathbf{2 0 0 8}$ & $\begin{array}{r}\mathbf{2 0 0 9} \\
\text { (est.) }\end{array}$ & $\begin{array}{r}\mathbf{2 0 1 0} \\
\text { (proj.) }\end{array}$ \\
\hline Russia industry & 35.5 & 40.6 & 53 & 65.9 & 70 & 89 \\
\hline Russia households & 25.6 & 31.7 & 41.6 & 52 & 51 & 63 \\
\hline \multicolumn{7}{|l|}{} \\
\hline Ukraine import prices & $\mathbf{7 7}$ & $\mathbf{9 5}$ & $\mathbf{1 3 0}$ & $\mathbf{1 7 9 . 5}$ & $\mathbf{2 3 2 . 5 4}$ & $\mathbf{2 5 5 . 1 5}$ \\
\hline Ukraine industry (state regulated) & 69.1 & 107.3 & 142.6 & 192.4 & 306.8 & 299.6 \\
\hline Ukraine households & 30.5 & 67.2 & 87.5 & 79.3 & 67.2 & 66.4 \\
\hline \multicolumn{7}{|l|}{} \\
\hline Belarus import prices & $\mathbf{5 5 . 1}$ & $\mathbf{5 5 . 1}$ & $\mathbf{1 1 8}$ & $\mathbf{1 2 6 . 5}$ & $\mathbf{1 5 1}$ & $\mathbf{1 7 1 . 5}$ \\
\hline Belarus wholesale (Beltransgaz) & 59.54 & 58.87 & $\mathrm{n} / \mathrm{a}$ & $\mathrm{n} / \mathrm{a}$ & $\mathrm{n} / \mathrm{a}$ & $\mathrm{n} / \mathrm{a}$ \\
\hline Belarus industry (Beltopgaz) & 72.3 & 75.16 & 141.7 & 171.3 & 205.5 & 261.3 \\
\hline Belarus households & 82.7 & 84.4 & 101.7 & 214.9 & 174.5 & 159.0 \\
\hline \multicolumn{7}{|l|}{} \\
\hline Moldova import prices & $\mathbf{8 0}$ & $\mathbf{1 6 0}$ & $\mathbf{1 7 0}$ & $\mathbf{2 3 2}$ & $\mathbf{2 4 5}$ & $\mathbf{2 4 2}$ \\
\hline \multicolumn{7}{|l|}{} \\
\hline European border price & $\mathbf{2 1 3 . 7}$ & $\mathbf{2 8 5 . 2}$ & $\mathbf{2 9 4 . 1}$ & $\mathbf{4 1 8 . 9}$ & $\mathbf{3 0 7 . 8}$ & $\mathbf{3 2 3 . 7}$ \\
\hline
\end{tabular}

Note. These are indicative prices only. Annual average exchange rates from the EBRD summary of economic indicators are used. For Russia, average prices in geographical price band 3 have been used. For Ukraine the 2010 import price is our estimate, based on reported prices for the first half of the year and government projections for the second half; household prices are average prices for households of under 2500 square metres, without a meter. For Belarus the 2010 import price is the price being charged under the contract; household prices are for those with meters and without gas-fired heating appliances. Source, Pirani (ed.), Russian and CIS gas markets, various chapters; Howard Rogers; government and company statements; author's calculations.

The financial crisis of 2008 brought the Russian economic boom to an end, and also hit Ukraine, itself heavily economically dependent on metals exports, very hard. Both countries went immediately into deep recession. But fiscally and financially Russia was in an infinitely better position: it used a large chunk of the oil windfall accrued in 2002-08 to restructure its state-dominated banking system, soften the blows of the crisis, and to try to stimulate recovery. Ukraine's banking system almost collapsed, and it took one of the IMF's largest

Ukrainian Gas Crisis of January 2009: a comprehensive assessment, OIES, February 2009; and Jonathan Stern and Katja Yafimava, The 2007 Russia-Belarus Gas Agreement (OIES, January 2007). 
emergency programmes to protect its state finances. The prospect of the economic hardship ahead, combined with the bad political relations between Moscow and Kiev, gave impetus to the most serious "gas war" of all in January 2009. The deal concluded after that dispute provided for Ukraine to start paying European netback prices, but with a $20 \%$ discount during 2009 to soften the blow. It also envisaged the tariffs charged by Ukraine to transport Russian gas to Europe being linked to those in the European market. The sharp increase in Ukrainian gas import prices in 2009 coincided with the slump and the resulting collapse of Ukrainian industrial production. Consumption of gas in Ukraine therefore fell sharply during 2009, but almost entirely among the industrial customers who pay higher prices than residential and public-sector customers.

The outlines of the Russo-Ukrainian gas trade, including both Ukraine's imports and its revenues from the transit of Russian gas to Europe, are shown in table 2. It can be seen that the combination of Russian efforts over the last five years or more to end discounts, and the effects in 2008-09 of the economic crisis, turned the terms of trade against Ukraine. Its gas import bill has risen steadily, interrupted only by the sharp reduction in import volumes caused by the crisis.

The effect of the 2009 "gas war" and the economic crisis on Naftogaz Ukrainy, was the collapse of the cross-subsidisation scheme it had been operating in its gas business. It had been using income from industrial customers, and state subsidies, to offset both the effect of non-payment, mainly by district heating companies, and prices both for those district heating companies and residential customers that were far below cost recovery. (This scheme, and the sources of financial loss in Naftogaz's gas business, are discussed in section 4(a): Consumption and the Causes of Naftogaz's Financial Problems, below.) In previous years, with the budget in relatively healthy condition, governments had been able to avoid dealing with Naftogaz's unsustainable business model. They provided substantial subsidies to compensate Naftogaz for below-cost gas tariffs, while at the same time Naftogaz paid a large tax bill. For example Naftogaz, according to its financial statements, received 1.295 billion hyrvnas (uah) (\$253 million) in tariff subsidy from the state budget in 2007, and 7.384 billion uah (\$1,393 million) in 2008. ${ }^{10}$

\footnotetext{
${ }^{10}$ NJSC "Naftogas of Ukraine", Consolidated Financial Statements, year ended 31 December 2008, p. 7. Conversions given using the annual average exchange rate, calculated by the EBRD.
} 
Table 2. Outline of Ukraine's gas and transit trade with Russia

\begin{tabular}{|c|c|c|c|c|c|c|}
\hline & 2005 & 2006 & 2007 & 2008 & 2009 & $\begin{array}{l}2010 \\
\text { (proj.) }\end{array}$ \\
\hline \multicolumn{7}{|l|}{ Imports } \\
\hline Volume imported, bcm & 55.8 & 53.3 & 50.1 & 48 & 26.8 & 36.5 \\
\hline Price $(\$ / \mathrm{mcm})$ & $44-80$ & 95 & 130 & 179.5 & 232.54 & 255.15 \\
\hline Value of imports, $\$$ billion & 3.2 & 5.1 & 6.5 & 8.6 & 6.24 & 9.3 \\
\hline \multicolumn{7}{|l|}{ Transit } \\
\hline Volume transited to Europe, bcm & 121.5 & 113.8 & 112.1 & 116.9 & 92.8 & 113.9 \\
\hline Volume transited to $\mathrm{CIS}, \mathrm{bcm}$ & 14.9 & 14.7 & 3.1 & 2.7 & 3 & 3 \\
\hline Cost of transit $(\$ / \mathrm{mcm} / 100 \mathrm{~km})$ & 1.09 & 1.6 & 1.6 & 1.7 & 1.7 & 2.75 \\
\hline Value of transit services, $\mathbf{\$}$ billion & 1.5 & 2.2 & 2.1 & 2.34 & 1.88 & 3.62 \\
\hline
\end{tabular}

Note: the 2010 price is our estimate, based on reported prices for the first half of the year and government projections for the second half.

Sources: Authors' estimates from Energy Charter Secretariat information, government and company statements, energy ministry statistics (for volumes and prices).

In 2009 state support for Naftogaz was increased to unprecedented levels. The IMF estimated Naftogaz's total operating deficit for the year at 2.5\% of GDP, or just under $\$ 3$ billion, and information from the finance ministry bears this out. The government spent 24.4 billion uah (just under $\$ 3$ billion) recapitalising Naftogaz, in addition to 4.13 billion uah ( $\$ 512$ million) paid in tariff subsidies. ${ }^{11}$ Ukraine dipped into its foreign exchange reserves in order to pay for this state support, issuing domestic bonds for the 24.4 billion uah, most of which were bought by the National Bank of Ukraine (NBU). During 2009, a drama was played out each month as political leaders and the NBU struggled to arrange payments for imported gas, under unusually strict payments terms. These terms had been inserted into the January 2009 contracts at Gazprom's insistence, after several years of disputes over late payment and nonpayment. On several occasions during the year, government bonds were issued and bought by the NBU, and the funds transferred to Naftogaz's balance. The IMF, which under its loan programme was monitoring Ukraine's finances closely, specifically endorsed such emergency practices. Even in December 2009, when the IMF had suspended its loan programme awaiting the outcome of the election, the Fund announced that it had agreed to

\footnotetext{
${ }^{11}$ IMF, Ukraine: Second Review Under the Stand-By Arrangement, September 2009; Ministry of Finance of Ukraine, Pro vikonannia Derzhavnoho biudzhetu Ukrainy za 2009 rik.
} 
Ukraine overstepping the fiscal limits laid down in the loan programme (i.e. lowering the Net International Reserves floor), in order to make its payment on time. ${ }^{12}$

The projected cost of imports in 2010 in table 2 is an important figure. The projection has been worked out on the basis of government and company statements about sales in the first and second quarters, and government projections of prices for the rest of the year (see also section 2(c): Import Prices and Transit Fees, below). The key point is that, because of the recovery in oil prices and therefore the continuing high level of European gas prices that Ukrainian import prices reflect, the total import bill will be substantially higher than in either 2008 or 2009, and - since a large proportion of it has to be financed by various types of government subsidies - it will remain a fiscal burden. The one positive point for Ukraine is that the fees it receives for transporting Russian gas to Europe also rise substantially (by more than $60 \%$ ) this year (2010), compared to last year, and revenue from these should reach record levels.

For all the drama surrounding the gas import payments, it should be underlined that they make up only one part of Ukraine's fiscal crisis, alongside the need to recapitalise the banking system, the breakdown of the state pension system, and the high level of spending on public services. In Table 3 the Naftogaz capital injection that was used to cover the company's operational deficit can be seen in the context of Ukraine's consolidated budget deficit for 2009:

Table 3. Ukraine's consolidated budget performance, 2009

\begin{tabular}{|ll|}
\hline & \% of GDP \\
\hline Official consolidated budget deficit & 2.3 \\
\hline SDR allocation, ${ }^{*}$ treated as budget revenues & 1.7 \\
\hline Bank recapitalisation & 2.0 \\
\hline Naftogaz capital injection & 3.2 \\
\hline $\begin{array}{l}\text { Implicit pension fund deficit (credits from unified } \\
\text { treasury account (state budget) to cover } \\
\text { pension fund expenditures) }\end{array}$ & 1.8 \\
\hline \begin{tabular}{l} 
Overall budget deficit \\
\hline
\end{tabular} & $\mathbf{1 1 . 0}$ \\
\hline
\end{tabular}

* An allocation of IMF Special Drawing Rights (interest-bearing international reserve assets), granted to a large number of countries including Ukraine in August 2009, as a low-cost way of adding to their international reserves. See $<$ http://www.imf.org/external/np/exr/faq/sdrallocfaqs.htm $>$ Note: 2009 GDP was 914.7 billion uah

Source: The Bleyzer Foundation, Ministry of Finance, NBU, Presidential Secretariat

12 “IMF Statement on Ukraine”, IMF Press Release no. 09/482, 30 December 2009. 
Naftogaz's situation in early 2010 may therefore be summed up as follows. A large gap had opened up in its finances as a result of the sharp increase in import prices and the simultaneous fall in industrial production, the collapse of the cross-subsidisation scheme, and the accumulated effect of hesitation over reform, below-cost prices and constant politicallydriven changes of management. On the other hand, there seemed to be little prospect of Naftogaz going bankrupt, since the government had made it clear that it would go as far as dipping into foreign exchange reserves - repeatedly - to make sure that did not happen. The IMF for its part supported the government in this regard, presumably guided by its determination not to allow fiscal collapse in any east European state.

At the time of writing the IMF is negotiating a new loan programme of up to $\$ 19$ billion with the new government, to cover the period to late 2012. Fund officials have been reported as saying that they are prioritising energy sector and pension reform, along with fiscal consolidation and anti-inflationary policy, as key issues in the negotiations. ${ }^{13}$ The Fund could delay or limit its new loan programme, in order to press these points, although it may refrain from doing so given the general nervousness about the financial stability of European states. Providing the Fund does not cancel its loan programme altogether, it is unlikely that Ukraine will fail to pay for its gas imports. Such non-payment seems the most unlikely trigger of a new "gas war"; a more credible cause of a dispute that would have an impact on transit would be if fragile aspects of the gas agreement with Russia, highlighted in the next section, break down. On the other hand it seems likely that Ukraine will continue to accumulate state debts in order to pay these gas import bills while simultaneously delaying energy sector reform. When and whether it can recover from the resulting fiscal problems will depend on the course of its economic recovery, on its relations with the IMF and on other factors, rather than on events in the gas sector alone.

\footnotetext{
13 "MVF dast Ukraine kredity v obmen na reformy", Deutsche Welle Russian language service, 7 June 2010.
} 


\section{THE AMENDMENTS TO THE GAS CONTRACTS}

\section{2(a): The Results of the Renegotiation, and Why They May Not Last}

The agreement signed between presidents Medvedev and Yanukovich on 21 April $^{14}$ provides for discounts on gas imports worth up to $\$ 40$ billion under current contracts that expire in 2019. In return, Ukraine will extend the lease on the Sevastopol base used by Russia's Black Sea fleet from 2017 to 2042, with a further five-year option.

Addenda to gas import contracts between Gazprom and Naftogaz Ukrainy, signed by their CEOs on the same day, ${ }^{15}$ provide for:

-- A discount of $30 \%$, capped at $\$ 100 / \mathrm{mcm}$, that covers most but not all of Ukraine's imports, and is equal to an exemption from export duty granted by the Russian government to Gazprom (i.e. the discount is funded by the Russian government). In 2010 the discount applies to $30 \mathrm{bcm}$ from an annual contract quantity (ACQ) of $36.5 \mathrm{bcm}$; in subsequent years the discount will apply to $40 \mathrm{bcm}$. Under the contracts, the ACQ would revert to $52 \mathrm{bcm}$ in 2011, but given demand levels in Ukraine this may well be subject to further revision.

-- The ACQ for this year (2010) was set in this agreement at $36.5 \mathrm{bcm}$, higher than the 33.75 bcm agreed in the contract as previously amended. This is composed of $6.5 \mathrm{bcm}$ delivered in the first quarter without a discount, and a further $30 \mathrm{bcm}$ to be delivered during the rest of the year with the discount. Deliveries were set at $6.474 \mathrm{bcm}$ for the first quarter; $8.0 \mathrm{bcm}$ for the second quarter; $9.326 \mathrm{bcm}$ for the third quarter; and $12.7 \mathrm{bcm}$ for the fourth quarter.

-- The base price (P0) in the Ukrainian import contract is unchanged. It was set when the contracts were signed, at the end of the January 2009 "gas war", and we argue (section 2(c): Import Prices and Transit Fees, below) that it is higher than the average of European import prices it is supposed to reflect. In the first quarter of 2010, Ukraine paid $100 \%$ of the base price, i.e. $\$ 305 / \mathrm{mcm}$. Second-quarter Ukrainian import prices, without the discount being

\footnotetext{
14 "Dogovor Ianukovicha i Medvedeva o bazirovanii flota do 2042 goda. Tekst dokumenta", Ukrainska Pravda, 22 April $2010<$ http://www.pravda.com.ua/rus/articles/2010/04/22/4956018/>.

15 "Kharkyvs'ke dopovenennia do gazovogo kontraktu Timoshenko-Putina. Tekst dokumentu", Ukrainska Pravda, 22 April $2010<$ http://www.pravda.com.ua/articles/2010/04/22/4956389/>.
} 
applied, are $\$ 336 / \mathrm{mcm},{ }^{16}$ which falls to $\$ 236 / \mathrm{mcm}$ after the discount is applied. The Ukrainian government estimates that the 2010 average price, with the discount, will be $\$ 234 / \mathrm{mcm}$, but this is necessarily an estimate since the actual price will depend on the level of oil prices in the last three quarters of the year.

-- The price formula and "take or pay" clauses in the contracts remain unchanged, but it was agreed to annul clauses 6.5 and 6.6 of the January 2009 supply contract, which provided for (6.5) failure to deliver the volumes (which has not happened) and (6.6) heavy penalties for failure to offtake monthly volumes of gas (which happened in 2009, with Gazprom waiving its right to levy the penalties). ${ }^{17}$

These agreements reduce the financial burden of gas imports on Ukraine, but (i) the total import bill may still be the highest ever, as discussed above, and (ii) crucial "fault lines" in the contracts remain, and are dealt with below. Attempts made during negotiations to repair these were largely unsuccessful.

Since January 2009 gas relations between Ukraine and Russia have been based on agreements made between prime ministers Putin and Timoshenko, and two supply and transit contracts concluded by Gazprom and Naftogaz, in the aftermath of the "gas war". ${ }^{18}$ These contracts contained several clauses that were highly unfavourable for Ukraine: a high base price, strict payment requirements, and take-or-pay clauses that imposed significant pressure on Ukraine's finances. This pressure was even stronger because of the continuing economic crisis, a sharp fall in Ukraine's gas demand in 2009, and the upward trend of oil prices.

The major reason that the Naftogaz-Gazprom supply contract is perceived in Ukraine as unfair is the high base price used. The "European" base price of $\$ 450 / \mathrm{mcm}$ for the first quarter of 2009, which is used in the contract's price formula to set quarterly prices, is closer to the upper end of what was paid for Russian gas by European buyers in 1Q 2009 when the contract was concluded. Whereas the contract envisaged a $20 \%$ discount for Naftogaz in 2009, from 2010 it envisaged Naftogaz paying Gazprom the full "European" price. The

\footnotetext{
16 “Tsena gaza dlia Ukrainy", UNIAN, 30 April 2010.

${ }^{17}$ This is our understanding of the text of the April 2010 contractual amendment. Gazprom sources state that standard take or pay penalties have not been removed and that the annulment refers to fines that Gazprom had the right to impose in addition to these penalties.
} 
contract also stipulated that if Naftogaz missed any monthly payment, on the seventh day of the month following the month of delivery, Gazprom has the right to require prepayment for all future deliveries.

Given this high base price, the actual price for Ukraine in 1Q 2010 was $\$ 305 / \mathrm{mcm}$, and in 2Q 2010 increased to $\$ 336 / \mathrm{mcm}$ (without the discount). The price for each quarter is calculated on the basis of oil product prices (50\% gasoil/50\% fuel oil) during the nine months preceding the month of delivery. Given that the oil price has been increasing, the average price for 2010, without the discount, has been estimated by the Ukrainian government at around $\$ 334 / \mathrm{mcm}$ (although, as noted above, it is impossible to make an accurate estimate of this type without knowing what oil prices will be in the last three quarters of 2010). However, the annual average price envisaged in the Ukrainian budget for 2010, as drafted in March, was much lower $-\$ 260 / \mathrm{mcm}$. During negotiations with the IMF on one hand and Russia on the other, Ukraine claimed that with a gas price of $\$ 260 / \mathrm{mcm}$, it would be able to set its budget with a $6 \%$ deficit, in line with IMF requirements. Thus the only way for the Ukrainian government to meet its budgetary target was to reduce the contractual price.

In addition to the high price, the "take-or-pay" clauses constituted another potential "fault line" in the contracts. Under the original contract, Naftogaz committed to buy an ACQ of 40 bcm in 2009 and 52 bcm in 2010 and subsequent years, with an 80\% annual "take-or-pay" requirement. There were also separate clauses setting monthly volumes and payment terms, with heavy penalties to be paid for lower off-take. Ukraine's gas demand declined dramatically by $26 \%$ in 2009 , and in November 2009 Gazprom agreed to reduce the ACQ to $27 \mathrm{bcm}$ in 2009 and to $33.75 \mathrm{bcm}$ in 2010. This change was documented in a separate contractual addendum; however, the ACQ remained unchanged at a level of $52 \mathrm{bcm} / \mathrm{year}$ for the subsequent period of 2011-2019. It was reported that, while the adjustments to the contracts in November were made by the companies, they were negotiated by prime ministers Putin and Timoshenko - a reminder of the politicised nature of the Russo-Ukrainian gas relationship.

Another key issue is that, while the supply contract has a "take-or-pay" obligation, the transit contract does not have a corresponding "ship-or-pay" obligation, and allows Gazprom to

\footnotetext{
${ }^{18}$ See Pirani, Stern and Yafimava, The Russo-Ukrainian Gas Crisis of January 2009, op. cit.
} 
reduce transit volumes across Ukraine, if need be, without penalty. In fact, while the transit contract stipulated $110 \mathrm{bcm} /$ year of transit volumes, actual volumes transited in 2009 were $24.2 \mathrm{bcm}$ below that level. ${ }^{19}$

It is important to note that the terms of use of, and access to, Ukrainian storage by Gazprom are not regulated by January 2009 supply and transit contracts, and appear to be based exclusively on a separate 25-year contract concluded between Naftogaz and Gazprom in July 2004. In the aftermath of the January 2006 crisis, when Gazprom ceased to be a supplier of gas to Ukraine, and Rosukrenergo became the only supplier, an addendum was signed by Naftogaz and Rosukrenergo whereby Naftogaz agreed to store gas for Rosukrenergo over a 30 -year period. Storage fees were set at an extremely low level, i.e. $\$ 2.25 / \mathrm{mcm}$; in August 2007 they were raised to $\$ 7.84 / \mathrm{mcm}$, still an enormous discount to European market levels. ${ }^{20}$ However, in January 2009, with the conclusion of new supply and transit contracts between Naftogaz and Gazprom, Rosukrenergo ceased to be a supplier of gas to Ukraine with Gazprom becoming the only supplier, but it is not clear whether the storage addendum was annulled. It is also not clear what the legal basis has been for storing Gazprom's gas in Ukraine during 2009-2010. Given that there have been no reports of the conclusion of a new storage contract, it is reasonable to assume that Gazprom has continued to store its gas in the Ukrainian storage on the basis of the old 2004 contract, hence paying Naftogaz a very low storage tariff, reportedly $\$ 4.95 / \mathrm{mcm}^{21}$

The 2009 supply contract committed Ukraine to allow Gazprom access to the domestic Ukrainian market via its 100\% subsidiary, Gazprom-Sbyt Ukrainy. The contract included a provision that Naftogaz would conclude a long-term contract with Gazprom-Sbyt to sell up to $25 \%$ of imported gas to Gazprom-Sbyt for direct sales to Ukrainian industrial customers. However, so far Gazprom-Sbyt has been operating on the basis of annual contracts with Naftogaz. The duration of Gazprom Sbyt's license is not known, but a three-year period is the shortest possible duration of such license under the Ukrainian law. ${ }^{22}$

\footnotetext{
${ }^{19}$ Alla Eremenko, 'Osobennosti pravki gazovykh kontraktov', Zerkalo Nedeli, 17-23 April, 2010.

${ }^{20}$ Whereas in western Europe customers usually pay an injection fee and then a withdrawal fee, and time periods are specified, it is our understanding that storage fees in the former Soviet Union, which are always quoted simply as a price per volume, cover the storage of that volume for the (annual) season. Iuliia Mostovaia, 'Sovershite vi massu otkritii (inogda ne zhelaya togo)', Zerkalo Nedeli, 4-10 February, 2006; Simon Pirani, "Ukraine: A Gas Dependent State", in Pirani (ed.), Russian and CIS Gas Markets, pp. 113-114.

${ }^{21}$ Discussion of Ukrainian storage capacity and utilisation can be found in section 3(d) below.

22 “A. Podmyshal'skii: Gazprom Sbyt Ukraina ne nuzhen demping”, Kommersant-Ukraina, 24 July 2008.
} 
In negotiations prior to the April agreement, Naftogaz Ukrainy reportedly proposed a number of amendments to the January 2009 supply and transit contracts, reflecting the contractual "fault lines" set out above. According to the Ukrainian weekly Zerkalo Nedeli, citing "reliable sources", Naftogaz proposed correcting the supply contract to allow for:

- a price reduction;

- a mechanism for changing the ACQ and the possibility of correcting quarterly volumes during each contractual year;

- elimination of the maximum 6\% deviation requirement for daily delivery volumes;

- elimination of "take-or-pay" fines and penalties;

- changing the payment schedule by either moving the date of payment to the $25^{\text {th }}$ of the month following the month of delivery, or making a $50 \%$ of payment on the $7^{\text {th }}$ and the rest on the $25^{\text {th }}$;

- amendment of the clause allowing Gazprom to suspend its contractual obligations if Naftogaz violated the contract. ${ }^{23}$

According to the same source, in respect of the transit contract, Naftogaz asked for:

- guarantees of minimum transit volumes of $110 \mathrm{bcm} / \mathrm{year}$;

- introduction of "ship-or-pay" requirements;

- changing the formula on the basis of which the transit fee is calculated.

While this long list of Ukrainian demands addressed the contractual "fault lines", Gazprom was fully satisfied with the contracts as they stood and had no clear motivation to agree to such amendments. Below we analyse in more detail these demands, and possible concessions in the gas sector that Naftogaz might make in exchange for them.

\section{2(b): The Course of the Negotiations, and Commentary}

From its first days in power, the new Ukrainian administration called on Russia to make a fresh start in gas relations and, in particular, to start negotiations on price reduction.

\footnotetext{
${ }^{23}$ Eremenko, “Osobennosti pravki gazovykh kontraktov”, op.cit.
} 
Ukraine's determination was signified by a number of high-level visits to Moscow during March and April. While it is known that Ukraine wanted to decrease import prices to \$250$260 / \mathrm{mcm}$, it is not clear whether it was asking for correction of the formula, or for a transitional period during which it would receive a discount from the contractual price. In our view Ukraine could have been asking for:

- reduction of the base price (which, although widely perceived as too high, is still within the range of prices paid by European countries) which would subsequently result in lower prices during the entire term of the contract (until 2020), and/or

- a gas price discount (determined on the basis of the existing formula) for a transitional period (as was the case with Belarus and Moldova when both secured a transition period of four years until 2011).

Success of either of these initiatives would probably be dependent on a way being found to compensate Gazprom for the resulting shortfall in revenues from gas sales to Ukraine. Gazprom had already made significant concessions to Ukraine in response to the collapse of Ukrainian gas demand, caused by the economic crisis of 2008-09, by agreeing not to apply contractual penalties against Naftogaz for (monthly and annual) failure to meet minimum offtakes in 2009, as well as by agreeing to reduce the ACQ from $52 \mathrm{bcm}$ to $33.7 \mathrm{bcm}$ in 2010 .

Despite the flurry of negotiating activity, progress initially remained limited. However, in early April, Russian prime minister Putin consented in principle to the negotiation of a price reduction. At the same time, he stressed that Gazprom was satisfied with the 2009 contracts, and hence these were to remain the only basis for Russia-Ukraine gas relations, and if any concessions were to be made on price, Ukraine would have to come up with "compensatory" offers acceptable to Russia and Gazprom. In turn, Gazprom CEO Aleksei Miller stressed that a price reduction would be dependent on the volumes taken by Ukraine, while noting that Ukraine had already taken less gas in 1Q 2010 than was envisaged by the contract. Ukrainian prime minister Azarov responded that Ukraine will take only as much gas as it needs.

However, on 9 April Gazprom and Naftogaz agreed that Naftogaz will buy $36.5 \mathrm{bcm}$ in 2010 instead of $33.7 \mathrm{bcm}$ as previously envisaged in the contract, with Gazprom confirming that Naftogaz's offtake in the first quarter was in line with the contract. Although no official 
statement was made by either side, on 16 April it was reported that Gazprom agreed to reduce import prices for Ukraine in exchange for the use of several of Naftogaz's storage facilities. It was also reported that an offer had been made to lease the storage facilities to Gazprom, which would have been a major commercial concession by Naftogaz. ${ }^{24}$ Neither the scale of discount offered in return, nor any details of the storage arrangements, were disclosed by the parties to the talks. Furthermore, on the next day, Russian deputy prime minister Sechin stated that the issue of price reduction was still being discussed. It later transpired that negotiations continued in Putin's Novo Ogarevo residence late into the evening of 20 April. The next day, in Kharkov, the intergovernmental agreements between presidents Yanukovich and Medvedev on the 25-year extension of the Black Sea Fleet lease, and the contractual addenda providing for the $30 \%$ price reduction were signed. ${ }^{25}$

There are three obvious reasons why the April agreement may be subject to further amendment.

First, and most important, the agreement is essentially political: by reducing the price for gas in exchange for extension of the Fleet lease, which was only to expire in 2017 at the earliest and 2020 at the latest, Russia has effectively made a pre-payment for the future lease of the naval base. Both sides have gone back to mixing commercial gas issues with political, nongas issues and, from the Russian perspective, giving up price increases so painfully achieved - and at such a high reputational cost - during 2006-09.

Second, while some of the clauses in the 2009 contracts that were most disadvantageous to Ukraine (such as the additional penalties for failing to take monthly volumes, and the $52 \mathrm{bcm}$ ACQ for 2010) have been removed, other "fault lines" remain, including: the relatively high base price for gas imports; the unfeasibly high ACQ; the combination of "take or pay" provisions for Ukraine and the lack of any "ship or pay" provisions in the transit contract.

Third, the lack of clarity on storage provisions leaves room for opaque practices, which in the past have obstructed the normalisation of commercial relationships and put transit arrangements at risk (see section 3(d): Ukraine's Storage Capacity, below).

\footnotetext{
24 “Ubedili", Vzgliad, 16 April 2010; "Vstrechnoe predlozhenie", Kommersant Ukraina, 16 April 2010,

${ }^{25}$ The old lease was not to expire until 2017, with a possibility of extension for a further five years (i.e., until 2022), provided that both countries agreed.
} 
Apart from these three points, the April 2010 agreement has further potentially negative consequences, as follows. In 2008-09, despite the sharp conflicts between Russia and Ukraine on gas prices and volumes, the two sides appeared to agree that their relationships in the gas sphere needed to be depoliticised and put on a commercial footing. The decision to exclude Rosukrenergo from the gas trade, and the price formulae in the January 2009 contracts, were steps in this direction. The April agreement has halted, and put into reverse, this depoliticisation process. This has clearly raised hopes among business groups that space has opened up to gain commercial advantage from political lobbying.

An obvious example of this is the lobbying activity by Dmitry Firtash, part owner of Rosukrenergo, around the 11.5 bcm of Rosukrenergo's gas in storage confiscated by Naftogaz in January 2009. The gas was confiscated in line with an agreement made with Gazprom at the same time as the conclusion of the January 2009 contracts. (Gazprom owns $50 \%$ of Rosukrenergo, and a Firtash company owns 45\%.) As discussed in previous material by the authors, ${ }^{26}$ an understanding was reached, essentially between the Russian and Ukrainian governments, that Rosukrenergo would be excluded from the transit business and would no longer be afforded the opportunity to sell central Asian gas in central Europe. Firtash and his colleagues attempted to challenge the confiscation in Ukraine both legally and politically, but failed, and then lodged a number of cases against Naftogaz at the arbitration court in Stockholm. The court was reported to have ruled in June 2010 that Naftogaz had to return to Rosukrenergo $11 \mathrm{bcm}$ of gas confiscated and $1.1 \mathrm{bcm}$ as compensation. The Ukrainian government said it was studying the possibility of an appeal. But alongside the legal process, Firtash has been, and presumably still is, pursuing the best possible deal by lobbying: judging the new government susceptible to such pressure, he made public demands for compensation and met with presidents Yanukovich and Medvedev during their discussions in Kyiv in mid-May. ${ }^{27}$

\footnotetext{
${ }^{26}$ Pirani, Stern and Yafimava, The Russo-Ukrainian Gas Dispute of January 2009, op. cit.

27 "Firtash trebuet u Naftogaza bolee 5 milliardov", Ukrainska Pravda, 20 May 2010; 'Dmitri Firtash poshel na neopravdannyi isk", Kommersant Ukraina, 21 May 2010; Alla Eremenko, "Naftogaz idet na mirovoe soglashenie s RosUkrEnergo?!", Zerkalo Nedeli 15 May 2010; Alla Eremenko, "Pirrovoe soglashenie?", Zerkalo Nedeli, 22 May 2010; Aleksei Nepomniashchii, "Vernut' tovarom", Vedomosti, 9 June 2010; "Boiko: 'Naftogaz Ukrainy' ne vernet gaz Rosukrenergo", Vedomosti, 9 June 2010; Irina Reznik, "Posrednik ne nuzhen", Vedomosti, 10 June 2010.
} 
Given all these factors, we argue that, although the financial burden on Ukraine, and the immediate prospect of a "gas war", have been reduced, the arrangements made are inherently unstable. Further renegotiation of the contracts is likely.

\section{2(c): Import Prices and Transit Fees}

We have noted our understanding above that the base price used in the 2009 contracts was higher than the majority of European import prices at that time. The relevant price information, insofar as it is publicly available, is shown in table 4.

Table 4. European, Ukrainian and Belarussian Gas Prices Compared

\begin{tabular}{|c|c|c|c|c|c|c|c|c|}
\hline$\$ / \mathrm{mcm}$ & Q1 09 & Q2 09 & Q3 09 & Q4 09 & Q1 10 & Q2 10 & $\begin{array}{l}\text { Q3 } 10 \\
\text { (proj.) }\end{array}$ & $\begin{array}{l}\text { Q4 } 10 \\
\text { (proj.) }\end{array}$ \\
\hline \multicolumn{9}{|l|}{ European border price } \\
\hline Average German Import Price & 398 & 300.83 & 259.5 & 281 & 280.66 & 318.96 & 343.13 & 352 \\
\hline \multicolumn{9}{|l|}{ Ukraine } \\
\hline Base price used for Ukrainian contract & 450 & 338.68 & 247.5 & 260.62 & 305.4 & 336 & 347.3 & 347.3 \\
\hline Ukrainian import price, with discounts* & 360 & 270.95 & 198 & 208.5 & 305.4 & 236 & 247.3 & 247.3 \\
\hline \multicolumn{9}{|l|}{ Belarus } \\
\hline Belarus import price & 210 & 157 & 115 & 119 & 169.22 & 184.79 & & \\
\hline \multicolumn{9}{|l|}{ Ukraine compared to Belarus } \\
\hline $\begin{array}{l}\text { Inferred European netback base price for } \\
\text { Belarus** }\end{array}$ & 262.5 & 196.25 & 143.75 & 148.75 & 188.02 & 205.32 & & \\
\hline $\begin{array}{l}\text { Ukrainian price net of export duty, } \\
\text { inferred (to Q2.10) and real (from Q2.10) }\end{array}$ & 315 & 237.07 & 173.25 & 182.43 & 213.78 & 236.00 & & \\
\hline $\begin{array}{l}\text { Inferred differential between Belarussian } \\
\text { and Ukrainian base prices }\end{array}$ & 52.5 & 40.82 & 29.5 & 33.68 & 25.76 & 30.68 & & \\
\hline
\end{tabular}

* i.e. discounts of 20\% in 2009, zero in Q1 2010 and 30\% from Q2 2010, as per contracts.

** Inferred from publicly reported import prices, and assuming a 20\% discount in 2009 and a $10 \%$ discount in 2010 , as per the intergovernmental agreement of 2007.

Table 4 shows that Ukrainian price levels during 2009 implied a base price that started more than $\$ 50 / \mathrm{mcm}$ higher than the Average German Import Price (AGIP), which is the best publicly-available indicator of the level of European import prices - whereas it should arguably have been lower, as the principle of European netback in Ukraine implies European prices less the additional transport cost (which is around $\$ 30 / \mathrm{mcm}$ ). In the second half of 2009, the Ukrainian base price fell below AGIP, but it rose above it again in the first half of 2010. The variations are probably accounted for by differences in the formulae used in contracts. European contracts, which are not published, are designed to reflect changes in oil product prices, with links to the prices of gas oil and fuel oil (and other indicators) in varying 
proportions. Since the beginning of 2010, increasing proportions of gas in some contracts are being priced with reference to gas spot markets. In any case, variations between the formulae used in the Ukrainian contract and other contracts, at a time of rapidly shifting prices, may explain the inconsistencies. Nevertheless, Ukrainian requests for the base price to be reviewed do appear to be justified. (On the other hand, even in the first quarter of 2010, when Ukraine was buying gas with no discount, the regulated tariffs for industrial customers were set leaving no, or almost no, margin for transport and supply. So the large number of claims by politicians that Ukrainian industrial customers were paying more than those in Germany appear exaggerated.)

Table 4 also shows the differential between Ukrainian and Belarussian import prices. In 2006 five-year contracts signed by Gazprom and the Belarussian oil and gas companies provided for a transition to a European netback price. Although the means by which this level was determined was not made public, the two sides announced that Belarus would pay $67 \%$ of European netback on $2008,80 \%$ in $2009,90 \%$ in 2010 and $100 \%$ in 2011 . The difference in transit costs for Russian gas exports to Ukraine and those for exports to Belarus are insubstantial and may be ignored for the purposes of comparison. However Belarus benefits from its membership of the customs union with Russia and Kazakhstan, which means that Gazprom does not pay export duty on gas exported to Belarus. We compare a base price used for Belarus (inferred from the import prices, which are publicly available, and the agreed level of discounts) and an inferred base price net of export duty for Ukraine, followed by the real price net of export duty from the second quarter of $2010 .{ }^{28}$ This comparison shows that an extra discount of $\$ 25-50 / \mathrm{mcm}$ seems to have been applied throughout to Belarus's import prices, presumably in return for its acceptance of Gazprom part-ownership of the Belarussian transit network, or for other concessions outside the gas sphere.

The Belarussian import prices in table 4 are those made public by Gazprom. However Belarussian ministers are arguing that prices this year should be no more than $\$ 150$ $155 / \mathrm{mcm}$, and are reported to have imposed payments at that level unilaterally. Consequently Gazprom's chief financial officer Andrei Kruglov said in late March that the company was owed $\$ 94$ million for gas deliveries to Belarus this year; subsequently this amount is reported

\footnotetext{
${ }^{28}$ Although in calculating nominal European netback prices for the Russian domestic market, the federal tariff service uses a $26.3 \%$ discount, to reflect the overall effect of the export duty, including on exports that are exempt from it.
} 
to have increased to $\$ 197$ million. If this issue is not resolved, a new gas dispute between Russia and Belarus is possible. ${ }^{29}$

\section{2(d): The Agreement from a Russian Standpoint: a Political Discount}

The discount on Ukrainian gas imports which, depending on price levels, is likely to amount to about $\$ 3$ billion per year, will be funded by the Russian government. The discount will be "equal to a reduction of the export duty on gas deliveries to Ukraine", according to a statement by Gazprom. ${ }^{30}$ This confirms the political character of the arrangement, and at least means that the Russian government has acknowledged that it should pay for such arrangements directly rather than via Gazprom's balance sheet.

As mentioned above, the discount on exports to Ukraine is to be applied to $30 \mathrm{bcm}$ of gas in 2010, and $40 \mathrm{bcm}$ in subsequent years. What remains unclear from the information available is whether Gazprom will benefit additionally from the sale on export markets of gas originating from central Asia, which is of course not subject to Russian export duty. The background to this is that in the 1990s and early 2000s most gas exported to Ukraine was - at least in the contractual sense, disregarding how physical volumes moved through the transport system - of central Asian origin. In 2006-08 purchases of central Asian gas were consolidated by Rosukrenergo, which sold this gas in Ukraine and central European countries net of Russian export duty. From January 2009, after Rosukrenergo exited the transit business, the purchases from central Asia - albeit sharply reduced, to $30-40 \mathrm{bcm}$ in 2009 again formed part of Gazprom's gas balance. It is not clear whether any of this gas was sold on export markets, net of Russian export duty, in 2009. Nor is it clear whether the exemption from duty of exports to Ukraine, announced in April 2010, is being applied to volumes of central Asian origin, or in addition to the duty-free export of those volumes to non-Ukrainian destinations. In the latter case, state revenues from export duty could be reduced by a further $\$ 3$ billion or more per year. It may be expected that this will be resolved in discussion between Gazprom and the finance ministry.

\footnotetext{
${ }^{29}$ As this paper was being prepared for publication, in late June, Gazprom reduced deliveries to Belarus and such a dispute appeared to be underway. Natalia Grib, "Gazprom poluchit paritet v Beltransgaze", Kommersant, 31 March 2010; “K Beltransgazu okhladeli?”, www.finmarket.ru, 28 May 2010.

${ }^{30}$ Gazprom press release, “Addenda to contract on gas supply to Ukraine signed”, 21 April 2010.
} 
The disconnect between government policy and Gazprom's commercial interest has not been lost on Ukrainian politicians and businessmen, who, since the conclusion of the April agreements, have called for the renewal of direct Ukrainian gas purchases from central Asia. Such purchases - mainly of Turkmen gas by Naftogaz, but also of smaller volumes of Uzbek gas by Ukrainian traders and steel producers - were stopped in 2005 by Gazprom, which displaced Naftogaz as the purchaser of Turkmen gas. Also, as operator of the Russian pipeline network, it permitted only Rosukrenergo as its chosen partner to transit volumes to Ukraine, refusing to accept e.g. Uzbek volumes owned by traders. ${ }^{31}$

Ukrainian politicians and businessmen may have concluded from the Russian government's readiness to fund discounted gas exports to Ukraine that they have the opportunity to press for further concessions. Renewal of direct purchases from central Asia is a concession that could bring rapid commercial advantage. So at a business forum attended by president Medvedev in Kyiv during his talks with Yanukovich, representatives of two of Ukraine's largest gas consumers - the Metinvest group controlled by Rinat Akhmetov, and power producers controlled by Konstantin Grigorishin - called for direct sales to be resumed. Prime minister Azarov said he had raised the issue in political negotiations with Russia. ${ }^{32}$

Gazprom may be expected flatly to resist such proposals. Were they to gain traction and/or Russian government support, they would be a further indication of the company's weakening position in central Asia, and specifically Turkmenistan. In 2005, when direct central Asian sales to Ukraine were stopped, Gazprom became the monopsonistic buyer of central Asian gas exports (except for Turkmen sales to Iran); only Rosukrenergo, in the framework of its overall business relationship with Gazprom, was able to access this gas; no threat was posed to Gazprom's market position in Europe and the CIS or to its pricing policy. In 2010, however, large-scale Turkmen exports to China have begun, and exports to Iran increased with the completion of an additional export pipeline; and since 2009 Gazprom has been forced to pay central Asian countries European-related prices. Direct sales of central Asian gas to Ukraine would further undermine Gazprom's position.

\footnotetext{
${ }^{31}$ See Simon Pirani, Ukraine's Gas Sector (OIES, 2007), pp. 31-34 and 35-38.

${ }^{32}$ Natalia Grib, "U Rossii snova prosiat gazovoi miagkosti”, Kommersant, 19 May 2010; "Ukraina rasschityvaet na vozvrashchenie v Aziiu", Interfax-Ukraina 20 May 2010.
} 


\section{2(e): The Russian-Ukrainian Deal in a European Gas Market Context}

At the same time as the April 2010 agreement was giving Ukraine some relief from European price parity, so traditional European gas pricing based (largely) on oil products was coming under increasing pressure due to a coincidence of:

- $\quad$ a fall in European (and global) gas demand due to financial crisis and economic recession;

- $\quad$ a surge in gas supply (mainly) from LNG projects (principally from Qatar) which started construction in the mid 2000s principally because of ... - $\quad$ the outlook for the North American gas market which has subsequently changed radically because of the success of developing unconventional - and especially shale - gas at much lower costs than previously expected. This has, to a significant extent, removed the need for North American imports of LNG, a substantial proportion of which are being redirected to Europe; and - $\quad$ stabilisation of crude oil prices around $\$ 70-80 / \mathrm{bbl}$.

These developments meant that, starting in late 2008, the price of gas at European market hubs fell to around half of the long term contract (oil related) prices and remained around that level up to the time of writing. ${ }^{33}$ With the exception of the UK's NBP, none of the European market hubs can yet be considered deep and liquid markets, and competition is still at an early stage. However, in the Netherlands and Germany, these is rapid growth in traded volumes and market participants, and daily prices are well-correlated across the north west European hubs, which increases confidence that manipulation of prices by large players can be avoided.

In the first quarter of 2010, it was reported in the press that Gazprom had agreed to include up to $15 \%$ of hub-based prices in its long term contract prices. The main issue for the future is whether crude oil prices at $\$ 70-80 / \mathrm{bbl}$ should be retained as the major price-setting mechanism for gas, particularly in countries - which include all of the major gas markets in Europe - where oil is overwhelmingly a transportation fuel and gas is a stationary fuel. For some years it has become increasingly questionable as to why the price of oil - set by some

\footnotetext{
${ }^{33}$ For details see Jonathan Stern, Continental European Long-Term Gas Contracts: is a transition away from oil product-linked pricing inevitable and imminent? (OIES, September 2009).
} 
combination of supply and demand, OPEC decision-making, speculative activity and market expectation - should be the decisive element of price formation for gas. The events of 200810 outlined above have starkly revealed this disconnect between oil and gas markets and likely future oil and gas prices.

The European-wide issue going forward is therefore whether the traditional oil product formula will remain as the major determinant of gas pricing. Our research has suggested that a transition is already underway towards hub-based pricing in Europe; but how fast this will move is uncertain. Gazprom's view is that the current pricing situation is a temporary phenomenon, caused by economic recession, which will disappear by 2012 , by which time demand will have recovered and traditional oil product-related pricing will return. However, it is unlikely - given what has been said above in relation to end uses of oil and gas - that, even with a tightening gas supply/demand balance, oil product pricing can be justified as a reflection of European gas market reality, particularly at oil prices in excess of $\$ 70 / \mathrm{bbl}$.

The relevance of these general comments for the Russia-Ukraine gas relationship is that, to the extent that a transition away from oil-linked gas pricing continues, and assuming that oil prices do not reduce and may even increase, the 2009 contract formula with its high base price will, even with the April 2010 discount, become a focus for dispute. Gazprom can be expected vigorously to resist any suggestion that Ukrainian prices should be linked to those on European hubs. But to the extent that the basis of prices charged for Russian gas in Europe changes, it should be expected that Ukrainian gas pricing will change similarly. A more radical view would be that gas prices charged to Ukraine should depend on specific Ukrainian energy and gas market conditions, but this would depend on the speed and extent of market reform discussed below.

\section{TRANSIT AND STORAGE ISSUES}

\section{3(a): The Transit Diversification Strategy of Gazprom and its Big Customers}

After its disputes with Belarus in 2004 and Ukraine in 2006, Gazprom's management resolved to invest in pipelines that increased its export capacity to Europe not only in line with its view of increasing export sales, but also to diversify gas transit to Europe away from both those countries. The "gas war" of January 2009 both strengthened Gazprom's resolve to 
push ahead with these transit diversification projects, and also increased support for such projects in Europe - and particularly in Germany - at both company and political level. Consequently, construction has begun on the Nord Stream pipeline, which will bring Russian gas to Germany via the Baltic Sea avoiding all transit states. The first string of the pipeline, with a capacity of $27.5 \mathrm{bcm} / \mathrm{year}$, is expected to be commissioned in late 2011; a second string, with the same capacity, in 2012. Gazprom and its large customers in southern Europe, particularly in Italy, are continuing negotiations with a series of transit countries over the more ambitious South Stream project that could carry up to $63 \mathrm{bcm} /$ year to European destinations via the Black Sea and the Balkans; an alternative, or addition, would be to increase the capacity of the existing Blue Stream pipeline from Russia to Turkey.

Table 5. Russian gas export capacity to Europe 2000-20

\begin{tabular}{|c|c|c|c|c|c|c|c|}
\hline \multirow[t]{2}{*}{$\mathrm{Bcm}$} & \multirow{2}{*}{$\begin{array}{l}2000 \\
\text { Actual }\end{array}$} & \multirow{2}{*}{\begin{tabular}{|l|}
2005 \\
actual
\end{tabular}} & \multirow{2}{*}{$\begin{array}{l}2010 \\
\text { est'd }\end{array}$} & \multicolumn{2}{|c|}{2015 projected } & \multicolumn{2}{|c|}{2020 proj. } \\
\hline & & & & $\max$ & $\min$ & $\max$ & $\min$ \\
\hline Finland & 5 & 5 & 5 & 5 & 5 & 5 & 5 \\
\hline Western Border-Belarus & 15 & 15 & 15 & 15 & 15 & 15 & 15 \\
\hline Belarus - Yamal 1 & 25 & 30 & 33 & 33 & 33 & 33 & 33 \\
\hline Western Border - Ukraine & 120 & 120 & 120 & 120 & 70 & 170 & 50 \\
\hline $\begin{array}{l}\text { Southwestern border- } \\
\text { Ukraine }\end{array}$ & 25 & 25 & 25 & 25 & 25 & 25 & 25 \\
\hline Blue Stream & 0 & 16 & 16 & 16 & 16 & 16 & 16 \\
\hline Nord Stream & 0 & 0 & 0 & 55 & 27.5 & 55 & 55 \\
\hline Blue Stream 2/South Stream & 0 & 0 & 0 & 30 & 0 & 63 & 16 \\
\hline TOTAL CAPACITY & 190 & 211 & 214 & 299 & 191.5 & 382 & 215 \\
\hline Exports to Europe* & 130 & 154 & 160 & 200 & 180 & 200 & 180 \\
\hline Spare capacity & 60 & 57 & 54 & 99 & 11.5 & 182 & 35 \\
\hline
\end{tabular}

* 2010 based on Gazprom estimates; 2010-2020 estimated under long term contracts giving an indication of minimum and maximum commitments.

Source: Adapted from Pirani (ed.), Russian and CIS Gas Markets, op. cit., Table 12.8.

Table 5 gives an overview of Russian export capacity to Europe in the last decade, and projects its development over the next decade, with minimum and maximum scenarios for 2015 and 2020. In the minimum scenario we have assumed (i) that by 2015, only the first string of Nord Stream (which is already under construction) is built, and that none of the southern routes will have been completed; (ii) that the second string of Nord Stream will be built by 2020, as will $16 \mathrm{Bcm}$ of extra capacity by expansion of Blue Stream; (iii) that there is 
no investment in the Ukrainian transport network and that its working capacity declines correspondingly; and (iv) that Russian exports to Europe are limited to the minimum volumes required by current long-term contracts. In the maximum scenario we have assumed (i) that both strings of Nord Stream and $30 \mathrm{Bcm}$ of South Stream capacity are built by 2015; (ii) that by 2020 some combination of South Stream and Blue Stream 2 will reach 63 Bcm; (iii) that there is substantial investment in, and expansion of, the Ukrainian network; and (iv) that Russian exports to Europe increase to $200 \mathrm{bcm} /$ year.

The conclusion is that, in the worst case for Ukraine - i.e. that Russia and its large customers prioritise investment in transit avoidance pipelines at the expense of other projects, and that no agreement is reached between Russia, Ukraine and EU countries on investing in the Ukrainian network - Russia could reduce the volumes of gas transited through the Ukrainian system to $45-50 \mathrm{bcm} /$ year by 2015 and to below that by 2020 . In the best case for Ukraine, that agreement is reached not only on refurbishment but on investment in its network, capacity could be increased. But the most likely outcome is that, over the next decade, transit flows will fall, even if not to the levels implied by the most pessimistic reading of the "maximum" scenario. It should also be borne in mind that, by the time the transit diversification pipelines are in operation, both Ukraine and Belarus will have gone a long way towards adapting to European-related import prices, and the completion of this process will anyway reduce the scope for the type of dispute that could disrupt transit.

\section{3(b): The Consortium Proposal}

During negotiations this year prior to the April agreements, Ukraine initially suggested the creation of a tripartite consortium, which would include Russian, European and Ukrainian partners. ${ }^{34}$ This consortium was envisaged to manage, modernise and expand the Ukrainian high-pressure transmission network - essentially a revival of the consortium proposed in 2002. Gazprom, Ruhrgas and Naftogaz were all involved in this initiative, but when lack of progress caused Ruhrgas to withdraw, the consortium became a Russia-Ukraine initiative reduced to focusing on a minor construction project which was eventually abandoned.

\footnotetext{
34 “Gazovye Shakhmaty”, Vzgliad, 5 March 2010.
} 
The consortium idea resurfaced, virtually unchanged, in 2010. Just as in 2002, Ukraine was only offering management rights to the other parties, but not ownership rights. Privatisation of the network was forbidden by law in Ukraine in 1995, and no-one in the new administration has mentioned the possibility of transferring or selling any part of the network to Gazprom or to any other foreign company. The network, which became the property of Ukraine at independence in 1991, is often portrayed as the national "family silver", and its sale would have been seen by many in Ukraine as the sale of statehood. More pragmatically, it is also seen as a lever to be used in disputes over import prices. Thus it would be extremely difficult for the Yanukovich administration to suggest privatisation and secure parliamentary approval, especially given the way the existing parliamentary coalition was formed.

While it would be difficult to win approval in Ukraine for privatisation of the network, a consortium to manage it may be "too little, too late" for Gazprom, because its focus has shifted to transit diversification. As for the European Commission, its silence on the renewed suggestion of a consortium has been notable. In March 2009, in the wake of the RussoUkrainian "gas war", the Commission arranged a conference in Brussels to discuss financing modernisation of the network, and said it was ready to provide a package potentially worth several billion dollars, in exchange for progress on gas market reform in Ukraine. Little or no progress was made on these proposals, mainly because little or no progress was made on market reform (see below). Nevertheless, the renewal of discussions on the consortium in March this year would have seemed to be an ideal moment - and a necessary one, from the standpoint of ensuring progress on energy issues - for the Commission to re-engage with this process. Up to the time of writing it has not done so, although president Yanukovich has made two visits to Brussels since his election. The Commission's hesitation may indicate indecision in Brussels about its overall political attitude to the new Ukrainian administration, or simply that the new Commission is taking some time to settle in.

Our conclusion is that the prospects for a consortium to manage the network are limited, and the possibility of attracting substantial investment resources to expand its capacity are negligible (although refurbishment would, to some extent achieve this). Gazprom and its main partners in Europe have voted with their euros, investing them in Nord Stream and potentially also in South Stream. They will want to see the Ukrainian system maintained, but have little motivation to invest in upgrading it: their interest in a consortium, while not having disappeared completely, has faded. If cooperation between the Russian and Ukrainian 
governments on economic projects prospers, that could help to break the logjam with the consortium. On the other hand the EC's indecision seems to be a negative factor.

\section{3(c): Gazprom's Strategy in Ukraine}

Have Gazprom's priorities vis-a-vis Ukraine changed since 2002, when it was keen on a consortium? And does the rationale behind Gazprom's interest in 2002 still hold in 2010? In our view, the major rationale in 2002 was to ensure transit security for Gazprom's exports to Europe by becoming the joint operator of the Ukrainian network. This rationale is no longer as strong as in 2002 because of significant progress made by Gazprom, together with its European partners, on the new transit avoidance infrastructure.

Gazprom has since 2002 gone through two major transit crises with Ukraine (in 2006 and 2009) - with disastrous consequences for its commercial reputation and its revenues. Gazprom and the Russian government emerged from these crises with a firm conviction of the ultimate unreliability of Ukrainian, and other CIS, transit routes and the need to prioritise transit avoidance infrastructure. A few months of experience of a government more friendly towards Russia, since the beginning of 2010, have not been enough to convince either political leaders or Gazprom managers to change this strategy. For example, prime minister Putin said at the start of the negotiating process with the new Ukrainian government that Russia's commitment to Nord Stream "of course reduces our interest in participating in work on the Ukrainian gas transport system. But we are still interested". ${ }^{35}$ The importance attached by Gazprom to transit avoidance is further signified by the fact that when the company had to make significant cuts to its investment programme in 2009, Nord Stream was not affected.

While Gazprom's rationale for involvement in the management of the Ukrainian network for transit security reasons is on the wane, the rationale for a stronger presence in the Ukrainian domestic market still holds. This is the same rationale that explains Gazprom's drive to acquire gas infrastructure assets throughout Europe. Gazprom has met significant resistance in many European countries and its successes in acquiring assets there have been very modest, but this task could be easier in Ukraine. Gazprom, badly hit by the demand collapse both in Europe and in the CIS, is keen to strengthen its presence in all markets where it can

\footnotetext{
35 “Namek na soiuz”, Energobiznes, 30 March 2010.
} 
make a profit. ${ }^{36}$ Therefore, Gazprom is probably interested in acquiring gas assets in Ukraine; (i) in the distribution sector, as some segments of the gas market are profitable, and some segments can be made profitable in the future if gas sector reform, including price reform, is implemented; and (ii) in the production sector, which suffers from a lack of investment that Gazprom arguably would be able to rectify.

Gazprom has been present in the Ukrainian distribution sector since April 2008 through its $100 \%$ subsidiary, Gazprom-Sbyt which, in line with the 2009 Gazprom-Naftogaz supply contract, supplies Ukrainian industrial consumers with up to $25 \%$ of gas imported by Naftogaz from Gazprom. Gazprom-Sbyt buys gas from Naftogaz and resells it directly to industrial users, bypassing regional distribution companies. Although the 2009 GazpromNaftogaz contract stipulates that the Gazprom Sbyt-Naftogaz relationship is to be based on a long-term contract, Gazprom-Sbyt has been operating on the basis of annual purchasing contracts. In order to strengthen its presence in Ukraine, Gazprom might ask for the conclusion of a long-term contract between Naftogaz and Gazprom-Sbyt, with a license to be awarded for the entire duration of such a contract. Gazprom might also ask for an increase in the percentage of imported gas to be supplied to domestic Ukrainian consumers by GazpromSbyt.

As long as Gazprom is interested in supplying the Ukrainian domestic market as well as in ensuring security of transit across Ukraine, it would presumably be interested in investing in the maintenance of the transport network (both high- and low-pressure), but it is doubtful that it would do so if no concessions were made on ownership rights. But as noted above, neither Gazprom nor its European partners participating in both Nord Stream and South Stream projects have any commercial rationale to be interested in the expansion of the Ukrainian network, as its current capacity is more than sufficient for serving the domestic market and for future transit requirements.

Gazprom's aims and objectives in Ukraine may therefore be summarised as follows. Its most urgent aim is to ensure security of transit across Ukraine until late 2011/early 2012 when Nord Stream 1 will be completed, and the likelihood of transit disruptions due to RussoUkrainian disputes will be significantly reduced. As the Nord Stream pipelines are

\footnotetext{
36 “A. Podmyshal'skii: Gazprom Sbyt Ukraina ne nuzhen demping”, op. cit.
} 
completed, the importance of transit across Ukraine will progressively decline, but Gazprom will still need to ensure the security of post-Nord Stream residual transit. Notably, whereas the transit dependence of north west European countries will be significantly reduced postNord Stream, that of south east European countries will remain high. Partial ownership of the Ukrainian high-pressure transmission network and storage would help Gazprom to achieve its aim of ensuring transit security across Ukraine until south east European countries can be reached by alternative pipelines. Other Gazprom aims are to increase its presence in the Ukrainian domestic market and possibly to invest in production assets.

\section{3(d): Ukraine's Storage Capacity}

During the negotiations in March and April, there were initially no reports on whether the issue of storage had been discovered. But, as mentioned above, it transpired on 16 April that improved terms for Gazprom's use of Ukrainian storage turned out to be the major compensation proposed by the Ukrainian side in exchange for a potential price decrease. In our view, this may have reflected Ukraine's failure to get a price concession through an offer to create a consortium to manage and modernise the Ukrainian network. More importantly, it served as a reminder that Ukraine's storage capacity could play an important part in the European gas supply and security picture, although not until there are great changes in the way that it is regulated and managed.

In the long term, Ukrainian storage capacity could become one of the most important elements of European storage, simply because of its volume and location. Thirty European countries surveyed by Gas Infrastructure Europe (GIE), not including Ukraine, have 75.4 bcm of active storage capacity, while Ukraine alone has storage capacity of between 32.1 bcm (as stated by GIE) and $40.1 \mathrm{bcm}$ (as stated by Naftogaz, see box below), more than half of which is physically located a few kilometres from Ukraine's western border. ${ }^{37}$ However, under the present arrangements Ukrainian storage cannot be used to its full capacity. The storage capacity, like the transit network, is owned by the state and managed by Naftogaz's transport subsidiaries. There are no third-party access arrangements and no publicly available information about the ownership of volumes or spare capacity.

\footnotetext{
${ }^{37}$ Gas Infrastructure Europe information stored and updated on line at $<$ https://transparency.gie.eu.com/ $>$, $<$ http://www.gie.eu/maps_data/storage.html $>$, and <http://www.gie.eu/maps_data/GSE/database/index.html $>$.
} 
While the main user of Ukrainian storage capacity is Gazprom - and it is an essential element for the company managing flows to the sales points for its largest customers, at or beyond the western border of Ukraine - the terms on which it does so are unclear. In 2005, Gazprom announced that a large quantity of gas belonging to it $(7.8 \mathrm{bcm})$ had been removed without authorisation from storage in Ukraine. (Rosukrenergo subsequently paid Gazprom for this gas.) Gazprom then announced that it would do its best to avoid using Ukrainian storage capacity. From 2006 Rosukrenergo became the largest customer for Ukrainian storage services, and acted as a storage agent for Gazprom. Since Rosukrenergo exited the transit business in January 2009, it is not clear how much Russian gas is stored in Ukraine and on what terms. During this year's negotiations, neither side has to date made any statement on the conditions of Gazprom's utilisation of Ukrainian gas stores, tariffs or possible changes in management/operatorship rights.

The issue of variations in the level of gas stored in Ukraine, the subject of considerable public discussion during 2009, is covered in the appendix at the end of this paper.

\section{UKRAINE AS A GAS IMPORTER, AND ITS DOMESTIC MARKET}

\section{4(a): Consumption and the Causes of Naftogaz's Financial Problems}

An underlying cause of the gas disputes between Russia and Ukraine is of course Ukraine's import dependence, which in turn results from the inefficient use of gas in the industrial sector, district heating systems and municipal housing networks inherited from the Soviet Union. Table 8 gives an outline of gas consumption in recent years.

Table 8. Ukraine's gas consumption in outline

\begin{tabular}{|l|r|r|r|r|r|}
\hline Bcm & $\mathbf{2 0 0 6}$ & $\mathbf{2 0 0 7}$ & $\mathbf{2 0 0 8}$ & $\mathbf{2 0 0 9}$ & $\begin{array}{r}\mathbf{2 0 1 0} \\
\text { (proj.) }\end{array}$ \\
\hline Total & $\mathbf{7 5 . 2}$ & $\mathbf{7 0 . 8}$ & $\mathbf{6 7 . 3}$ & $\mathbf{5 2 . 8}$ & $\mathbf{5 6}$ \\
\hline Industry & 24.3 & 25.8 & 23.2 & 13.5 & 16 \\
\hline Power sector & 8.6 & 8.4 & 7.5 & 5.0 & 5 \\
\hline District heating & 12.8 & 10.5 & 10.0 & 10.1 & 10 \\
\hline Residential \& public sector & 21.4 & 19.1 & 19.6 & 17.8 & 18 \\
\hline Technical gas & 8.1 & 7.0 & 7.0 & 6.4 & 7 \\
\hline
\end{tabular}

Source: energy ministry statistics / Energobiznes 
The dramatic fall in consumption in 2009 , caused by the economic recession, immediately catches the eye. Ukraine suffered a $15.1 \%$ fall in GDP in 2009, the deepest recession in any former Soviet and eastern European country except Latvia and Lithuania, and registered a $21.9 \%$ fall in industrial output and a $46.2 \%$ fall in investment. This slump in the "real economy" was the main reason for the $22 \%(14.5 \mathrm{Bcm})$ reduction in gas consumption. As the table shows, the decline in consumption was largest in the industrial sector, where consumption fell by $9.7 \mathrm{Bcm}(42 \%)$ year on year. The next largest percentage decline was in power generation, where demand fell by $33 \%(2.5 \mathrm{Bcm})$ as generating companies switched to coal-fired capacity to reduce exposure to higher gas prices. Consumption in the residential and public sector fell by $1.1 \mathrm{Bcm}(6 \%)$ and there was a slight increase in the district heating sector. The expectation for 2010 is that gas consumption will return in line with the slow and incomplete recovery of the economy. In industry, spare capacity is likely to be restarted, consuming gas as inefficiently as it did before the recession; in the residential and district heating sectors, inefficient consumption was relatively unaffected by the recession. Gas usage in power generation is not expected to recover to 2008 levels.

Table 9 gives a more detailed breakdown of consumption in 2009, together with information on prices charged to different groups of customers and estimates of receipts from gas sales. The intention is to present a picture of the causes of the financial problems concentrated in Naftogaz's gas business.

Naftogaz does not publish separate accounts for its gas business, or sufficiently detailed financial information for the effect of government policies and price levels on the business to be measured precisely. But it does publish sufficient data for the main outlines of the problem to be clear. The scale of the problem can be judged from the IMF's report that Naftogaz's operational deficit in 2009 was $2.5 \%$ of GDP, i.e. 22.86 billion uah. The main sources of this deficit appear to be (i) non-payment by Naftogaz customers for gas supplied (assuming that non-payment is bad debt that will be written off) and (ii) sale of gas at below cost recovery level. Statistics published by the energy ministry on debts owing to Naftogaz Ukrainy for gas delivered in $2009^{38}$ are shown in column 7 of Table 9: the total debts are recorded as 10.668 billion uah ( $\$ 1.32$ billion) in total, the lion’s share of which, 6.383 billion uah ( $\$ 791$ million),

\footnotetext{
38 “Raschety za prirodnii gaz s NAK 'Naftogaz Ukrainy' na 1.01.10 (po kategoram potrebitelei)”, Energobiznes, 19 January 2010.
} 
is owed by district heating companies. The remainder of the operational deficit is presumably the difference between the company's receipts from sales of gas and the cost of the gas, of the services supplied, overheads, etc.

Table 9. Naftogaz Ukrainy's Debts

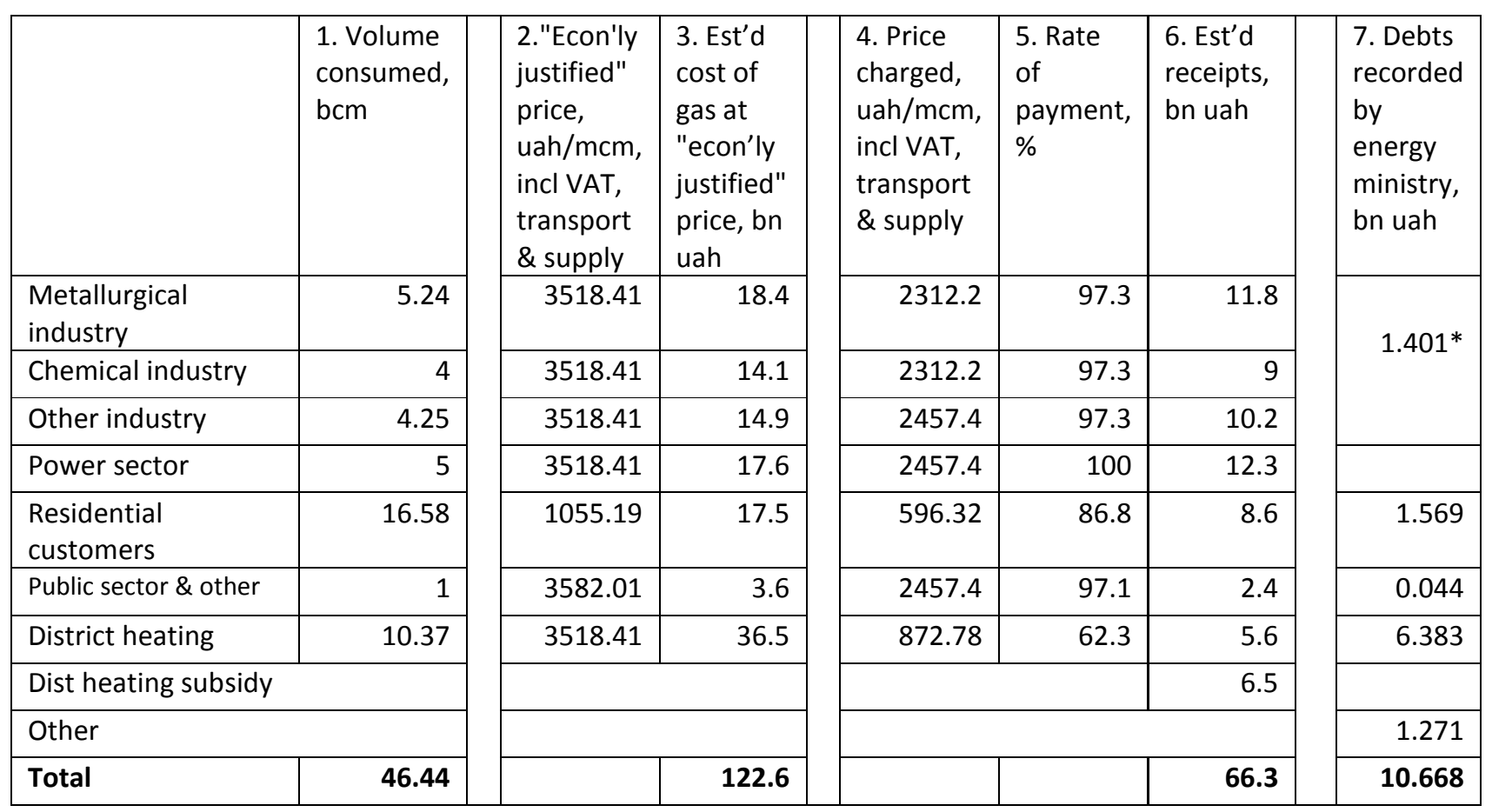

* For all industry

Note: Volumes consumed, and debts in the last column, are based on energy ministry statistics.Prices and rates of payment are from Naftogaz. Estimates of cost of gas and of receipts are the authors'. The table excludes technical gas, and there are small variations from table 8 due to variations in the original statistics.

In Table 9, the prices charged to consumers for gas (including VAT, transport, supply fee, etc) are given in column 4. Using these figures, and published statistics on volumes, we have estimated the company's receipts for gas sales in column 6 . The figures in column 4 are published by Naftogaz. ${ }^{39}$ The price for residential customers is assumed to be an average, as there are a large number of different tariffs charged to residential customers according to the size of their property and whether or not they have a meter installed. The authors have adjusted the prices for metallurgical and chemical industry customers to take account of a discount introduced into the tariff by the government in early $2009 .{ }^{40}$ Finally the figures have

\footnotetext{
39 “'Otnositel'no pokazatelei finansovo-khoziaistvennoi deiatel'nosti NAK 'Naftogaz Ukrainy' v 2008-2009 godakh", Naftogaz web site < http://www.naftogaz.com/www/2/nakweb.nsf?Open>, 5 March 2010.

${ }^{40}$ The discount is referred to in the "Preiskurant na prirodnii gaz" published on the Naftogaz web site during 2009 but currently unavailable.
} 
been adjusted according to the average level of payment in each sector, information on which is published regularly by Naftogaz. The estimated receipts from gas sales must however be subject to several caveats. First, there are various exceptions and amendments to the prices quoted that may not be fully reflected. Second, gas to industrial customers is sold via traders or district gas companies. Some of it is sold wholesale without the expense of transporting it via low-pressure pipelines, and the way that Naftogaz shares transport and supply revenue with these companies is complex and not reflected in Table 9. Third, gas used by Ukrtransgaz and district gas companies for technical and other purposes (i.e. to fuel compressor stations, but also in their repair businesses and in losses) is not included in the table. Nevertheless the total of 66.3 billion uah ( $\$ 8.21$ billion) is at least a rough estimate of receipts. From these receipts, Naftogaz must pay costs, including the estimated $\$ 6.24$ billion spent on Ukraine's gas imports in 2009; about $\$ 500-800$ million spent on domestically-produced gas; other operational outgoings, which we have made no attempt to quantify; and return of VAT to the state, and other taxes.

Columns 2-3 of Table 9 present the "economically justified" prices published by Naftogaz. The company does not spell out what is included in these prices (i.e. whether they provide for capital investment as well as operational expenses, and at what level), but says that prices below this level for any category of customers must be paid for by higher prices for other categories of customers and/or by direct state subsidy. In contrast, the international financial institutions have been arguing that prices must be raised to cost recovery level (a similar concept to "economically justified" prices) and that subsidies should be limited to direct payments to poorer parts of the population, rather than cross-subsidies or state subsidies to Naftogaz. Nevertheless, the figures do provide a basis to estimate the revenues from the gas business that Naftogaz believes are needed to make it viable, and we have done this in column 3. A comparison of the estimated revenue at these prices with the estimated receipts at present, i.e. between columns 3 and 6 , reflects the potential gain to be made by Naftogaz from tariff increases. It also highlights (i) that Naftogaz believes that industrial, as well as residential and district heating, customers continue to pay prices well below the "economically justifiable" level, and (ii) that the most serious gap in Naftogaz's finances is in the district heating sector, where revenues at "economically justified" prices would be more than six times the current estimated revenues, and more than three times the sum of current estimated revenues and the current subsidy paid by government. It should further be noted that the company set its "economically justifiable" price for residential customers at 1055.19 
$\mathrm{uah} / \mathrm{mcm}(\$ 130.75 / \mathrm{mcm})$, presumably because, from an accounting point of view, it treats gas sold to residential customers as domestically-produced gas, which it buys from its own subsidiaries and joint ventures at around $\$ 25-40 / \mathrm{mcm}$. In contrast to Naftogaz's approach, most proposals for market reform would imply abolishing the two-tier price structure, on the basis that the differential itself is damaging to the development of the market.

Another conclusion from Table 9 is that the two main elements in the payments gap in Naftogaz's gas business - the differential between cost-recovery (or "economically justifiable") prices and current prices, and non-payment - are a reminder of the difficulties of gas sector reform. Governments hesitate to proceed with tariff increases because they are unpopular with residential and other customers, and opposed by interest groups in business. Moreover in current economic conditions they may also be aware that tariff increases will lead to increased non-payment, which, as the table shows, stems mainly from the district heating sector. This is why gas sector reform and broader municipal services reform inevitably go hand in hand.

\section{4(b): Gas Sector Reform}

The future of the domestic Ukrainian gas market, and to some extent the future of the consortium proposal for the gas transport system discussed above in section 3(b), depend in the first instance on the reform legislation under discussion in parliament.

This legislation was drafted following a conference on the Ukrainian gas sector hosted by the European Commission on 23 March 2009. The conference ended with the adoption of a joint statement by the EC and Ukraine, which provided on one hand for a financing package of up to $\$ 5$ billion from the World Bank, EBRD and European Investment Bank to be put in place for the Ukrainian transport system, and on the other for Ukraine to press ahead with gas sector reform. The law was then drafted, with a view to Ukrainian ratification of the Energy Community Treaty (EnCT), as a result of which it would join a group of south-east European countries that are parties to the Energy Community, which aims to coordinate energy policy, develop infrastructure, and harmonise legislation with the EU acquis. ${ }^{41}$ The draft law made

\footnotetext{
${ }^{41}$ The parties to the Energy Community are: the European Union and eight Contracting Parties (Albania, Bosnia \& Herzegovina, Croatia, FYR Macedonia, Moldova, Montenegro, Serbia and the UN Interim Administration
} 
provision for the restructuring of Naftogaz, including separation of its transport, production and distribution divisions; for EU-type market access rules covering transport, storage and distribution; and for an independent regulator to set tariffs according to EU guidelines.

The draft gas law was the subject of consultation and discussion in parliamentary committee, but did not get to the first reading stage under the Timoshenko government. The financing package for the pipeline system made equally little progress and, although the World Bank continued its work with Ukraine on energy sector restructuring, no additional loans were disbursed. When the Azarov government was appointed in March this year, the gas market reform draft, along with other draft laws that did not reach their first reading, was returned from parliament to the government in accordance with parliamentary procedure. The government made some drafting changes; confirmed its commitment to the draft, in line with Energy Community accession, in a May 2010 instruction on European integration; included reform of the oil and gas sector, and municipal services sector, in its programme of economic reforms for 2010-2014, including commitments to major items agreed with the EU (restructuring of Naftogaz, access rules, price reform, etc); and the draft was returned to the parliamentary process. ${ }^{42}$

During the year up to May 2010, therefore, the process of gas sector reform moved neither substantially forward nor substantially backward. The political position of the new government and its supporters in parliament appears to be similar to that of the last government and its supporters: there is no parliamentary party that is opposed outright to the principle of reform, but there are many who do not see it as a priority, and some who are against it because of its impact on business interests to which they are aligned. Whether or not the reform is adopted, or watered down in the course of the parliamentary process, probably depends on the relative success of the economic reformers in government, and the business interests opposed to reform, in influencing parliament.

\footnotetext{
Mission in Kosovo.) Observers are Georgia, Norway, Turkey and Ukraine. See $<$ http://www.energycommunity.org/portal/page/portal/ENC_HOME>.

42 "Rosporiadzhennia KMU vid 19.05.2010 no 1073-r "Pro zatverdzhennia planu pershchocherhovikh zakhodyv shchodo integratsyy Ukrainy do Evropeis'koho Soiuze na 2010 rik"; "Zamozhne suspil'stvo, konkurentospromozha ekonomika, efetyvna derzhava: programa ekonomichykh reform na 2010-2014 roki”, published on the Zerkalo Nedeli web site <www.zn.ua>, 29 May 2010. A leaked draft of the government's new Memorandum on Economic and Financial policy also suggests that the government is committed to pushing through the draft gas sector reform law; see Ukrainska Pravda, 14 April 2010,

$<$ http://www.pravda.com.ua/articles/2010/04/14/4935767/>. It was mistakenly reported in some European media that the draft gas law had been withdrawn.
} 
As noted above, the IMF may be able to bring pressure to bear in favour of various market reforms, including gas sector reform, in the course of its negotiations with Ukraine. Another factor that may influence the outcome of the reform process is the interest of Gazprom in the Ukrainian transport system, and to some extent the interest of Gazprom and other Russianbased business groups in working in the Ukrainian domestic gas market.

Given the structure of the Ukrainian gas market, there are two ways in which Gazprom could strengthen its presence in Ukraine. Firstly, Gazprom could attempt to increase the volume of gas that Gazprom-Sbyt is allowed to market in Ukraine directly (currently up to $25 \%$ of imports), either by increasing the percentage or by increasing the volume. Gazprom could attempt to secure a long-term purchase contract between Gazprom-Sbyt and Naftogaz, matching the duration of the January 2009 Gazprom-Naftogaz supply contract, and secure a long-term (instead of annual) license to serve the domestic market.

Secondly, Gazprom, via Gazprom-Sbyt, could also attempt to acquire ownership stakes in the regional gas companies, which distribute and supply gas to residential, public sector and some industrial customers. There have already been acquisitions of regional gas companies by Russian and Ukrainian business groups. A recent survey estimated that, out of 45 regional gas companies, 22 were owned by Rosukrenergo or affiliated structures in the business group headed by Dmitry Firtash; five by the Russian-based Renova group, headed by Viktor Vekselberg, which also has major interests in the municipal services sector in Russia; two by the Ukrainian-owned Sodruzhestvo group; and others by various Ukrainian business groups. ${ }^{43}$ Under the previous government, the regional gas companies, which collect payment for gas on Naftogaz's behalf, had accumulated considerable debts to Naftogaz, reported to be around $\$ 1$ billion by November $2009 .{ }^{44}$ On the grounds of this non-payment, the previous government announced a policy of dispossessing the owners of regional gas companies. It directed Naftogaz during 2009 to transfer shareholdings in regional gas companies to a $100 \%$ Naftogaz subsidiary, Naftogazmerezhi; it also requested the regulator to revoke licenses to supply gas to industrial users from those regional gas companies that had accumulated debt to Naftogaz. Under the new government, it appears that the policy of dispossessing the regional

\footnotetext{
${ }^{43}$ Viktor Tarnavskii, "Vlasteliny konforki”, Energobiznes, 24 February 2009.

44 “'Iu. Timoshenko: oblgazy s 1 iianvaria 2010 mogut byt' lisheny litsenzii na postavku gaza prompotrebiteliam", <http://economics.unian.net/rus/detail/27032>.
} 
gas company owners is being reversed. The regulator has annulled the Naftogazmerezhi licence and Naftogaz has announced that it will be merged into its domestic sales division, Gaz Ukrainy. ${ }^{45}$ Moreover, licences for most regional gas companies have been extended for five years. Assuming that government policy accepts the ownership of regional gas companies by Russian-based business groups, Gazprom could also decide to enter this market.

Another aspect of Gazprom's policy towards Ukraine, which may have encouraged it to agree to the deal in April, may have been its unwillingness to see Ukraine reforming its gas sector in line with the EU acquis - which the Ukrainian government should have done, but so far has not done - in order to get external financial support to pay an undiscounted price for gas. To prevent Ukraine from reforming in such a way that Gazprom would not be able to influence the course of reform, Gazprom might have judged it beneficial to give Ukraine a discount on price, in which case Europe's leverage over Ukraine would weaken and Ukraine's domestic business lobby would defend the preservation of the status quo. At the same time, Gazprom is interested in making Ukraine a more profitable market for its gas, and hence it is interested in reform, but only reform under which its interests would be secured. However, since Ukraine has not conceded any ownership rights over its transport network to Gazprom, it has retained significant influence over its future domestic gas sector reform.

One possibility is that the Energy Charter Treaty (ECT), and in particular its Transit Protocol, which clarifies the issues of transit absent from the acquis, could serve as a framework within which Ukraine, the EU and Russia could find common ground on how to proceed with reform of the Ukrainian gas sector. This is however the least likely of the options available.

The analysis presented leads us to conclude that the following options are available for Ukraine:

- preserve the status quo, i.e., neither to reform the gas sector nor to concede part ownership of the network to Gazprom;

- implement an acquis-style reform, as committed to under the March 2009 Ukraine-EU Declaration and the Energy Community Treaty (EnCT);

\footnotetext{
45 “NKRE annulirovala litsenziiu 'Naftogazmerezhi'”, UNIAN news agency, 29 April 2010.
} 
- a "third way" - reform the gas sector but not necessarily on the basis of the acquis, possibly on the basis of bilateral deals with Russia and/or the EU, possibly within the multilateral framework on the basis of the ECT/TP.

In our view, preserving the status quo is a road to nowhere. To make progress, Ukraine will have to start reforming its gas sector, in terms of both pricing and restructuring. As noted above, the course of reform will be decided in part by the relative impact on the process of the economic reformers in government and business groups who perceive a negative impact on their interests from the reform. In addition, external players - Russia on the one hand, the EU on the other, and also the IMF, to which Ukraine is now deeply indebted following the financial crisis - will seek to influence the process.

\section{CONCLUSIONS}

From this analysis of the new agreements and the other developments mentioned, we draw the following conclusions.

First. By agreeing to exchange a price discount on Ukraine's gas imports for a political concession outside the gas sphere, the extension of the Black Sea naval base lease, the Russian and Ukrainian governments have halted and partially reversed the progress they had made towards depoliticising, i.e. commercialising, their gas relations.

Second. The amendments to the January 2009 contracts leave a number of crucial "fault lines" in the contractual relationship between Gazprom and Naftogaz Ukrainy. In particular: the high base price for Ukrainian imports; the lack of a "ship or pay" clause in the transit contract that might reasonably be expected to mirror the "take or pay" clause in the supply contracts; the removal of the penalties for failure to offtake, or to supply, monthly volumes, which weakens the "take or pay" obligations and increases uncertainty about the consequences of the contractual parties failing to meet their obligations. The existence of these "fault lines" may add to the temptations for both sides, in view of the larger economic and political difficulties they are likely to face, to reopen negotiations on the contracts. This, and the reversal of progress towards depoliticising gas relationships, suggests that the April 2010 agreement is unlikely to be any more durable than that of January 2009; further changes can be expected. 
Third. The warmer political relationship between the new Ukrainian government and the Russian government make future "gas wars" - i.e. disputes leading to supplies to Europe being disrupted - less likely in the short term. But the uncertainties surrounding the contracts imply a potential for disputes. Reduction in gas prices will make it easier for Ukraine to pay for its imports and, despite its considerable fiscal problems, Ukraine is unlikely to get into a position where inability to pay for imports triggers a dispute: such a scenario would only materialise in the relatively unlikely event of a further deep economic downturn and/or the complete cancellation of the IMF programme for Ukraine. On the other hand disputes could arise from issues left unresolved by the negotiations on contracts.

Fourth. IMF pressure via threats to limit or slow down its loan programme for Ukraine might stimulate energy sector reforms and improve Ukraine's payment position. But the IMF's attitude to its programme in Ukraine is likely to be shaped as much by its wider concerns about sovereign defaults in Europe and the need for fiscal consolidation as by its specific concern about Ukrainian governments' failure to reform.

Fifth. Both Gazprom and its large European customers have decided, as the result of previous disputes, to invest in transit diversification pipelines to reduce dependence on Ukraine and Belarus. The first of these, the Nord Stream 1 pipeline, will be commissioned in late 2011 or early 2012 at the latest. This will substantially reduce the bargaining power of both Ukraine and Belarus on import prices; furthermore, both countries will most likely have made considerable progress by that time in adapting to European-related prices. The era of "gas wars", in the form that was experienced during 2004-09, will probably end in 2011-12.

Sixth. A corollary of the advancement of transit diversification strategies is that the significance of the Ukrainian transit network - both for Gazprom and its western (but not its eastern) European customers, and for the Ukrainian economy - will diminish. In an extreme case, that no political agreement is reached between the EU, Russia and Ukraine on investment for refurbishment and maintenance of the network, Ukraine could become a residual transit route of last resort. The obvious solution to this problem, first proposed by the German, Russian and Ukrainian presidents in 2002, was for a consortium to manage the network. In the five years that followed the "Orange revolution" of 2004, the political impetus for this project was lost, with Gazprom and European energy companies investing in 
other pipeline routes. The January 2009 "gas war" further damaged its chances, and in 2010 there is little likelihood of a transport consortium being formed, although it is not yet impossible. While new ways may be found to invest in maintenance of the network, the chances of substantial investment in expansion of the Ukrainian network are negligible.

Seventh. The lack of clarity over the use and management of Ukraine's storage capacity further hinders progress towards the Ukrainian transit network's potential being realised. The huge potential of Ukraine's storage assets will not be realised until gas sector reforms have made substantial progress, including the introduction of third-party access.

Eighth. Without gas sector reform, and especially reform of Ukraine's gas pricing structure, it is difficult to see how its gas market can progress. And yet whether and how quickly reform will be implemented is very hard to foresee. Prospects for reform should be improved by the new Ukrainian government's pragmatic approach to economic policy and its intention of balancing the country's foreign economic policy between Russia and the EU. But this alone does not guarantee implementation of reform. While some of the business groups that influence the government would probably welcome reforms, others have no reason to. Some politicians also remain reluctant, both because reform involves unpopular decisions on tariffs and because it disrupts vested interests. A more rapid economic recovery, which will depend in large part on external factors such as the situation in the world market for steel and steel products, would create better circumstances for reform.

\section{APPENDIX: LEVEL OF GAS STORED IN UKRAINE}

During the Russo-Ukrainian gas dispute of 2009, and for much of the year afterwards, concern was expressed both by Gazprom and by European politicians about the possibility that the transit of gas via Ukraine to Europe might be adversely affected by the levels of gas in storage being run down to dangerously low levels. Fears were expressed (a) that if insufficient gas for Ukrainian domestic consumption was stored before the winter season, this would endanger both supply to Ukrainian customers and the reliable transit of Russian gas to Europe, and (b) that if excessive gas was pumped out of storage, this would leave insufficient cushion gas with resulting technical damage to the facilities. ${ }^{46}$ Further concerns

\footnotetext{
${ }^{46}$ See Pirani, The Impact of the Economic Crisis on the Russian and CIS Gas Markets, p. 39.
} 
were expressed when the previous Ukrainian government published its draft gas balance for $2010,{ }^{47}$ which envisaged a net withdrawal from storage of $9.5 \mathrm{bcm}$ of gas during 2010 . Although storage levels are the subject of a great deal of public comment, there is insufficient information in the public domain for observers to make a proper judgment about whether any risk is posed to gas transit by this issue, and if so, what type of risk. Here we set out the information available to us.

Natural gas in any storage system comprises active gas, that is gas used to balance different levels of demand at different times, and cushion gas, that remains in storage at all times to sustain the level of pressure.

Active gas. There is little information in the public domain (1) about the actual total amount of active gas stored at any particular time (no statistics are published; politicians and Naftogaz executives report the level of active gas in storage from time to time); and (2) about the level of active gas storage required for the safe operation of the transit network and supply of Ukrainian customers in the winter season (which itself varies depending on winter temperatures). Active gas capacity (i.e. the maximum active gas that could be stored) is reported by Naftogaz Ukrainy as 40.68 bcm (see table 2A below).

Monthly statistics compiled by the Ukrainian fuel and energy ministry are published showing the amounts of gas injected into, and withdrawn from, storage, but not on the total amount of active gas stored. These amounts are reproduced in table 1A, which covers the four years 2006-09, in the first two columns. The third column, "level of active gas storage, public information", records statements by government ministers or Naftogaz executives, reported in the press, about the total level of active gas storage at the end of some months. The estimates of the volume of active gas stored at the end of each month, in the final column, have been made by assuming that the statement made about the level of storage at the end of January 2008 was correct, and extrapolating from there, both forwards and backwards in time, using the statistical information about amounts pumped into and withdrawn from storage. The estimates accord with official statements made in October 2007 and July 2008, but differ quite widely from statements made during 2006 and 2009.

\footnotetext{
${ }^{47}$ Order of the Cabinet of Ministers no. 1679 from 29 December 2009, which set out a draft 2010 gas balance.
} 
Table 1A. Estimated levels of active gas stored in Ukraine

\begin{tabular}{|c|c|c|c|c|c|c|c|c|c|}
\hline Month & $\begin{array}{l}\text { Pumped } \\
\text { in to } \\
\text { storage, } \\
\text { bcm }\end{array}$ & $\begin{array}{l}\text { With- } \\
\text { drawn } \\
\text { from } \\
\text { storage, } \\
\text { bcm }\end{array}$ & $\begin{array}{l}\text { Level of } \\
\text { active } \\
\text { gas } \\
\text { storage, } \\
\text { public } \\
\text { info } \\
\text { (end of } \\
\text { month) }\end{array}$ & $\begin{array}{l}\text { Level of } \\
\text { active } \\
\text { gas } \\
\text { storage, } \\
\text { OIES } \\
\text { estimate } \\
\text { (end of } \\
\text { month) }\end{array}$ & Month & $\begin{array}{l}\text { Pumped } \\
\text { in to } \\
\text { storage, } \\
\text { bcm }\end{array}$ & $\begin{array}{l}\text { With- } \\
\text { drawn } \\
\text { from } \\
\text { storage, } \\
\text { bcm }\end{array}$ & $\begin{array}{l}\text { Level of } \\
\text { active } \\
\text { gas } \\
\text { storage, } \\
\text { public } \\
\text { info } \\
\text { (end of } \\
\text { month) }\end{array}$ & $\begin{array}{l}\text { Level of } \\
\text { active } \\
\text { gas } \\
\text { storage, } \\
\text { OIES } \\
\text { estimate } \\
\text { (end of } \\
\text { month) }\end{array}$ \\
\hline Jan-06 & 0 & 3.732 & & 12.436 & Jan-08 & 0 & 4.181 & 19.4 & 19.4 \\
\hline Feb-06 & 0 & 2.541 & & 9.895 & Feb-08 & 0 & 3.02 & & 16.38 \\
\hline Mar-06 & 0 & 1.782 & & 8.113 & Mar-08 & 0 & 1.256 & & 15.124 \\
\hline Apr-06 & 0.653 & 0.649 & & 8.117 & Apr-08 & 0.949 & 0.936 & & 15.137 \\
\hline May-06 & 1.951 & 0 & & 10.068 & May-08 & 2.634 & 0 & & 17.771 \\
\hline Jun-06 & 3.359 & 0 & & 13.427 & Jun-08 & 3.398 & 0 & & 21.169 \\
\hline Jul-06 & 3.324 & 0 & 11 & 16.751 & Jul-08 & 2.197 & 0 & 23.3 & 23.366 \\
\hline Aug-06 & 3.783 & 0 & & 20.534 & Aug-08 & 3.051 & 0 & & 26.417 \\
\hline Sep-06 & 3.745 & 0 & & 24.279 & Sep-08 & 1.88 & 0 & & 28.297 \\
\hline Oct-06 & 1.337 & 0.575 & & 25.041 & Oct-08 & 1.48 & 4.082 & & 25.695 \\
\hline Nov-06 & 0 & 2.959 & & 22.082 & Nov-08 & 0.352 & 0.444 & & 25.603 \\
\hline Dec-06 & 0 & 3.078 & & 19.004 & Dec-08 & 0 & 2.314 & 29.5 & 23.289 \\
\hline Jan-07 & 0 & 2.385 & & 16.619 & Jan-09 & 0 & 4.927 & & 18.362 \\
\hline Feb-07 & 0 & 1.927 & & 14.692 & Feb-09 & 0 & 3.266 & & 15.096 \\
\hline Mar-07 & 0.411 & 1.198 & & 13.905 & Mar-09 & 0 & 3.129 & & 11.967 \\
\hline Apr-07 & 1.384 & 0.192 & & 15.097 & Apr-09 & 0.974 & 0.102 & 16.8 & 12.839 \\
\hline May-07 & 2.732 & 0 & & 17.829 & May-09 & 1.904 & 0 & 17 & 14.743 \\
\hline Jun-07 & 3.763 & 0 & & 21.592 & Jun-09 & 0.698 & 0 & & 15.441 \\
\hline Jul-07 & 3.922 & 0 & & 25.514 & Jul-09 & 2.803 & 0 & & 18.244 \\
\hline Aug-07 & 3.387 & 0 & & 28.901 & Aug-09 & 2.893 & 0 & & 21.137 \\
\hline Sep-07 & 2.172 & 0 & & 31.073 & Sep-09 & 1.209 & 0 & 26.3 & 22.346 \\
\hline Oct-07 & 0.274 & 0.665 & 31.2 & 30.682 & Oct-09 & 0.033 & 0.18 & & 22.199 \\
\hline Nov-07 & 0 & 3.634 & & 27.048 & Nov-09 & 0.278 & 0.886 & & 21.591 \\
\hline Dec-07 & 0 & 3.467 & & 23.581 & Dec-09 & 0.234 & 2.08 & 23.8 & 19.745 \\
\hline
\end{tabular}

Source: energy ministry statistics / Energobiznes; company and government statements; own calculations

The estimates in the table are presented in the form of a graph, in Chart 1A. 
Chart 1A. OIES estimates of the level of active gas stored in Ukraine, bcm

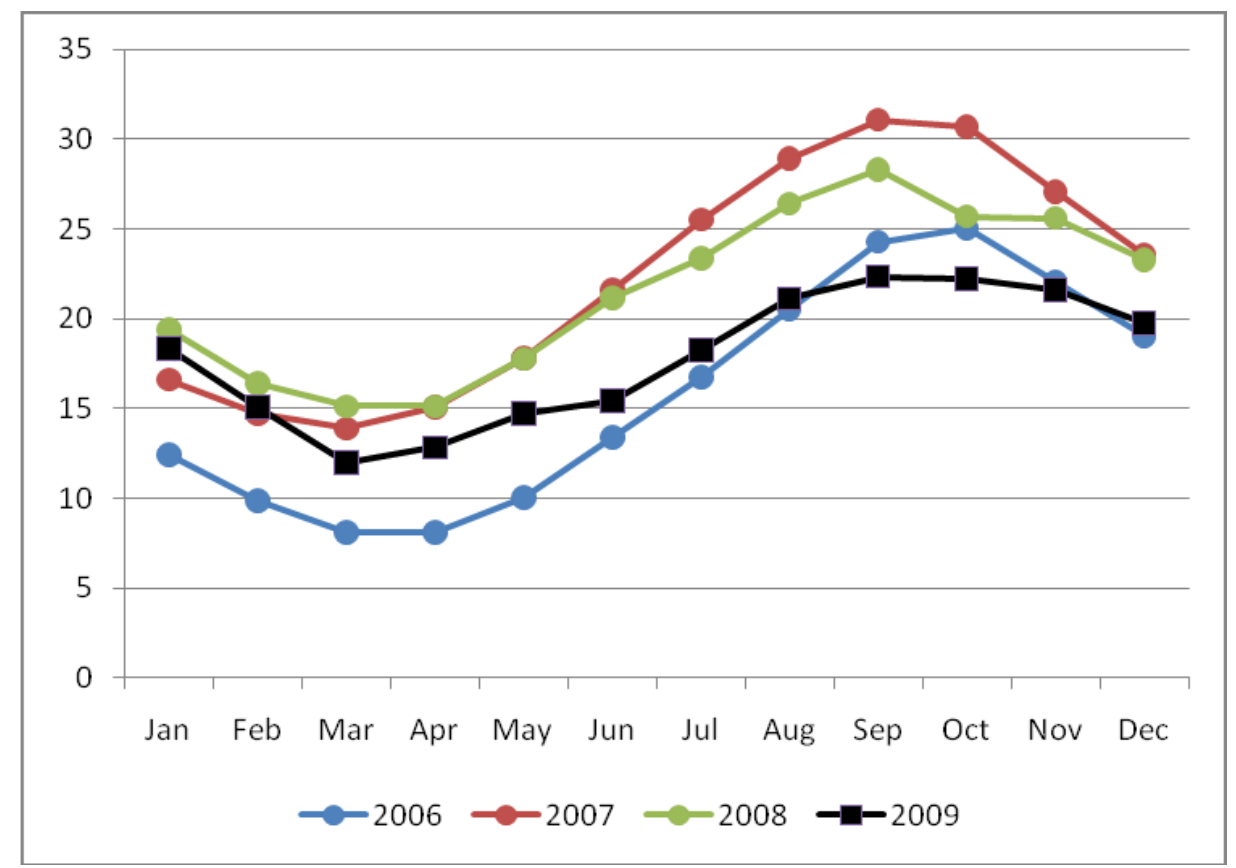

The following observations may be made about the information in the table and chart.

- Assuming the statistics are correct, the lowest level of storage in the last four years was during 2006. Our estimates suggest that in March-April of that year it may have fallen to just above $8 \mathrm{bcm}$. In any case the statistics show that it was lower in 2006 than for most of the subsequent three years.

- The statistics show that in 2009 the level of storage was lower than in 2007 or 2008 , but higher than in 2006, except in September-November. This was a period during which concern was being expressed both by Russia and the EU about the level of storage, and the public statement made at the end of September 2009 by Naftogaz, that $26.3 \mathrm{bcm}$ was in storage, was a considerable overstatement, if the statements made in January and July 2008, and the statistics, were correct.

- However the statistics also show that considerable effort was made to make up the shortfall in storage during those months. Indeed the ministry statistics, which do not usually specify the sources of gas stored, specify that $2.257 \mathrm{bcm}$ of the $4.135 \mathrm{bcm}$ of gas injected into storage in August-October 2009 was of Ukrainian origin, implying that a decision was made to replenish storage from this cheaper Ukrainian-produced gas.

- The estimated levels stored in Ukraine in 2009 were lower than in the two preceding years but only briefly lower than in 2006. Given that demand in Russia, Ukraine and the EU was at a historic low in 2009, this does not seem surprising. But without additional information about the technical requirements of the transit system and the rate at which stored gas is supplied to Ukrainian customers, it is impossible to say whether the concern expressed about the level of storage was justified. 
Cushion gas. In all storage systems, cushion gas remains in place at all times. Recent information from Naftogaz, displayed in Table 2A, suggests that in the Ukrainian storage system, about $43 \%$ of total capacity is taken up by cushion gas. This does not seem to be high by international standards; for example a recent survey by market regulators in the USA showed that cushion gas averaged about $54 \%$ of total operating capacity there in 1975-91 and had increased to $61 \%$ by $2000 .^{48}$

Table 2A. Active and cushion gas storage in Ukraine $\mathrm{U}^{\underline{49}}$

\begin{tabular}{|c|c|c|c|c|}
\hline Storage & $\begin{array}{c}\text { Total } \\
\text { capacity, } \\
\text { bcm }\end{array}$ & $\begin{array}{l}\text { Active gas } \\
\text { capacity, } \\
\text { bcm }\end{array}$ & $\begin{array}{l}\text { Cushion } \\
\text { gas, bcm }\end{array}$ & $\begin{array}{c}\text { Share of } \\
\text { cushion } \\
\text { gas, \% }\end{array}$ \\
\hline Bilche-Volitsko-Uherske & 33.5 & 21.2 & 12.3 & $37 \%$ \\
\hline Proletarske & 8.8 & 4.4 & 4.4 & $50 \%$ \\
\hline Dashavske & 5.265 & 2.15 & 3.115 & $59 \%$ \\
\hline Oparske & 5.05 & 2.4 & 2.65 & $52 \%$ \\
\hline Uherske & 3.95 & 2 & 1.95 & $49 \%$ \\
\hline Bohorodchanske & 3.42 & 2.3 & 1.12 & $33 \%$ \\
\hline Chervonopartizanske & 3 & 1.5 & 1.5 & $50 \%$ \\
\hline Solokhivske & 2 & 1.2 & 0.8 & $40 \%$ \\
\hline Verhunske & 2 & 1 & 1 & $50 \%$ \\
\hline Kehichivske & 1.6 & 1 & 0.6 & $38 \%$ \\
\hline Hlibivske & 1.6 & 0.8 & 0.8 & $50 \%$ \\
\hline Krasnopopivske & 0.8 & 0.42 & 0.38 & $48 \%$ \\
\hline Olishivske & 0.66 & 0.31 & 0.35 & $53 \%$ \\
\hline Total & 71.645 & 40.68 & 30.965 & \\
\hline
\end{tabular}

Source: Naftogaz Ukrainy

The information presented in Table 1A indicates that at no time in the last four years did the level of active gas in storage fall anywhere close to zero, implying that there was no danger presented to the volumes of cushion gas. It should be noted, though, that in some storage systems the ability to pump gas out of storage at the required rate is constrained once the volume of active gas stored falls below a certain level. It is not known whether this is true of the Ukrainian stores and at what level such constraints might become material.

\footnotetext{
${ }^{48}$ Federal Energy Regulatory Commission, Current State Of and Issues Concerning Underground Natural Gas Storage (30 September 2004).

${ }^{49}$ These figures vary, but not significantly, from those published by the IEA in 2006. See IEA, Ukraine Energy Review 2006, p. 212.
} 